PRZEGLĄD BIBLIOTECZNY 2019 z. 4 PL ISSN 0033-202X

\title{
DARIUSZ GRYGROWSKI
}

Wydział Dziennikarstwa, Informacji i Bibliologii

Uniwersytet Warszawski

e-mail: dargry@uw.edu.pl

ORCID: 0000-0003-2155-2931

\section{BIBLIOTEKI AKADEMICKIE W NOCY - CZ.1 - DOŚWIADCZENIA ZAGRANICZNE}

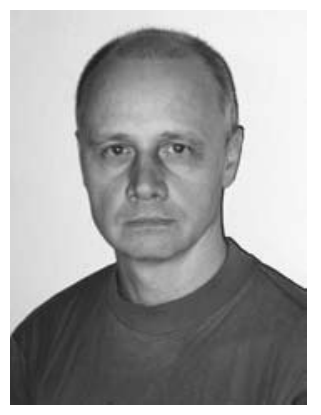

Dariusz Grygrowski, dr hab., adiunkt w Katedrze Badań nad Bibliotekami i Innymi Instytucjami Kultury na Wydziale Dziennikarstwa, Informacji i Bibliologii Uniwersytetu Warszawskiego. Autor książek Dokumenty nieksiążkowe w bibliotece (Warszawa: Wydaw. SBP, 2001) i Biblioteki i pieniądze (Warszawa: Wydaw. SBP, 2015). Od 2013 r. redaktor kwartalnika „Przegląd Biblioteczny”.

SŁOWA KLUCZOWE: Biblioteki akademickie - organizacja i zarządzanie. Biblioteki akademickie - godziny otwarcia. Biblioteki akademickie - nocna obsługa użytkowników.

ABSTRAKT: Teza/cel artykułu - Zapis 24/7 oznacza dostępność wszelakich usług świadczonych całą dobę przez siedem dni w tygodniu. W kontekście działalności bibliotecznej oznacza to jednak nie tylko możliwość całodobowego korzystania z usług bibliotecznych w rozumieniu dostępu wirtualnego, ale również permanentny dostęp do czytelni biblioteki i jej zbiorów w sensie fizycznym. Faktycznie jednak takich bibliotek, które przez większość roku otwarte są przez całą dobę, jest na świecie stosunkowo niewiele. Natomiast obserwuje się tendencję wydłużania godzin pracy bibliotek, a przodują w tym biblioteki akademickie, odpowiadając w ten sposób na oczekiwania studentów. Celem artykułu jest przedstawienie doświadczeń zagranicznych bibliotek akademickich w zakresie nocnej obsługi użytkowników. Metody badań - Analizie zostały poddane publikacje z zakresu organizacji i zarządzania bibliotekami, zwłaszcza prezentujące wyniki badań i analiz wykorzystania bibliotek w porze nocnej. Uzupełnieniem były informacje na stronach WWW bibliotek akademickich dotyczące godzin otwarcia w zwykłych okresach roku akademickiego i w czasie egzaminów końcowych. Wyniki i wnioski - Badania potrzeb 
użytkowników i pomiary liczby odwiedzin bibliotek akademickich w godzinach nocnych zdecydowanie przekonują że wydłużanie godzin pracy jest uzasadnione. Spadek liczby użytkowników w kolejnych godzinach nocnych jest spodziewany i oczywisty. Jednak liczba osób chcących korzystać z bibliotek uczelnianych około północy (a nawet dłużej) jest przeciętnie na tyle wysoka, że potwierdza zasadność decyzji o wydłużeniu czasu pracy $\mathrm{w}$ pewnych okresach roku akademickiego.

\section{WSTĘP}

Umberto Eco w swoim pamiętnym eseju O bibliotece określił idealną bibliotekę jako „wielką machinę spędzania wolnego czasu”, która powinna być "otwarta w godzinach dogodnych dla wszystkich" (Eco, 2007, s. 47-48). Autor miał na myśli również godziny wieczorne, pisząc, że lubi w różnych krajach odwiedzać biblioteki właśnie otwarte wieczorami (Eco, 2007, s. 23). Jako przykład bibliotek przyjaznych w ten sposób dla użytkownika wskazał zaś dwie biblioteki północnoamerykańskie - uniwersytetów w Yale i w Toronto - otwarte wówczas do północy, również w niedziele (Eco, 2007, s. 24). Dziś, prawie cztery dekady po tym, jak Eco napisał swój esej, z owym słynnym 19-punktowym wzorcem złej biblioteki, książnica otwarta do północy, zwłaszcza biblioteka akademicka, w wielu krajach nie jest już zjawiskiem wyjątkowym, wskazywanym jako wzór do naśladowania, a można wręcz wskazać wiele przykładów bibliotek, które godziny swojej pracy jeszcze bardziej wydłużyły. Czasem do godziny 2:00 w nocy, czasem do 5:00 nad ranem, a czasem nie są zamykane wcale i pracują 24 godziny na dobę.

Zachęcanie do spędzania nocy $\mathrm{w}$ bibliotece jest praktykowane jako forma promocji bibliotek i czytelnictwa - głównie przez biblioteki publiczne. Przykładem jest akcja „Noc bibliotek”, która jako przedsięwzięcie ogólnopolskie organizowana jest od 2015 r. Jej cztery pierwsze edycje w latach 2015-2018 odbywały się w maju, co oczywiście nawiązywało do majowego tygodnia bibliotek. Tymczasem piątą edycję przeniesiono na październik 2019 r. Faktycznie jednak pojedyncze biblioteki organizowały własne akcje „Noc w Bibliotece” lub „Noc z Andersenem” już kilka lat wcześniej, zanim akcja "Noc bibliotek" nabrała rozmachu i ogólnopolskiego charakteru. Biblioteki naukowe również organizują podobne akcje promocyjne i popularyzatorskie, np. przy okazji „Nocy Muzeów”. Zazwyczaj ustalony jest wtedy program o charakterze zdecydowanie bardziej rozrywkowym niż naukowym ${ }^{1}$. Są to zatem okolicznościowe przedsięwzięcia popularyzatorskie, rodzaj happeningu organizowanego raz do roku. Tymczasem

${ }^{1}$ Zob. np. A. Folga, J. Kołakowska: „Noc w Bibliotece” Uniwersytetu Pedagogicznego w Krakowie. „Poradnik Bibliotekarza” 2011, nr 2, s. 27-28; A. Bułdak, A. Buszta: "Noca w bibliotece Uniwersytetu Rzeszowskiego licho nie śpi..." - innowacyjne formy promocji biblioteki. W: Koncepcje organizacji bibliotek. Pod red. M. Wojciechowskiej. Gdańsk 2012, s. 147-153. 
biblioteki mogą udanie - o czym świadczą liczne przykłady zagraniczne i nieliczne polskie - funkcjonować w godzinach nocnych także w sposób standardowy i regularnie, a nie tylko na zasadzie jednorazowych wydarzeń kulturalno-promocyjnych.

O szczególnych doznaniach, jakie mogą się pojawić podczas korzystania z biblioteki w nocy, pisał Alberto Manguel w książce pt. Biblioteka $w$ nocy. Przypisał nocnej porze te szczególnie nastrajające właściwości, dzięki którym biblioteka nabiera specyficznego uroku i tajemnicy, gdzie ożywają duchy, gdzie porządek ustanowiony przez katalogi jest w półmroku umowny i traci na znaczeniu (Manguel 2008, pp. 14-15). Szczególny nastrój nocy odnosi przede wszystkim do swojej dużej prywatnej biblioteki, gdyż - jak pisze - „często siedzi nocą wśród swoich książek, bo choć woli pisać rano, czytać lubi w gęstej ciszy nocy" (Manguel 2008, p. 193).

Pewnego rodzaju zauroczenie, o którym pisze Manguel, a które można zapewne odczuwać podczas korzystania w nocy z biblioteki, jest na pewno stanem godnym przeżycia i rozmyślań, ale jednak nie o takie postrzeganie biblioteki chodzi w zawartych poniżej rozważaniach na temat dostępności bibliotek akademickich w godzinach nocnych. Nie chodzi więc o to, by otwarta w nocy biblioteka była azylem dla osób poszukujących nokturnowych doznań. Korzystanie z publicznie dostępnej biblioteki w nocy ma bowiem nieznacznie odbiegać od pracy w ciągu dnia, nawet jeśli biblioteka nie jest wówczas w pełni funkcjonalna, bo niektóre usługi są ze względów organizacyjnych niedostępne. Nie ma więc potrzeby stwarzać w nocy w bibliotece jakiejś szczególnej atmosfery. Oświetlenie ma funkcjonować normalnie, bez zmniejszania natężenia. Urządzenia techniczne - kopiarki, skanery, drukarki - powinny być gotowe do użytku i pracować bez obawy, że po ich włączeniu pryśnie nokturnowy nastrój. Wymagania w kwestii zachowania ciszy i porządku powinny być standardowe, a nie szczególnie restrykcyjne.

\section{4/7 - KWESTIE ORGANIZACYJNE}

Zagadnienie nocnej, a nawet całodobowej obsługi użytkowników $\mathrm{w}$ bibliotekach, bywa $\mathrm{z}$ pewnym uproszczeniem omawiane $\mathrm{z}$ użyciem zwięzłego i rozpoznawalnego symbolu 24/7. Tymczasem bibliotek, które rzeczywiście $\mathrm{w}$ pełnym wymiarze praktykują ten system, jest mało, a tam, gdzie ciąg dni, w których biblioteka jest otwarta bez żadnej przerwy, przekracza 7 - najczęściej takie rozwiązanie wprowadza się w sumie tylko na kilka tygodni w roku. W pozostałych okresach ogranicza się liczbę dni pracy całodobowej tylko od trzech do pięciu w tygodniu albo wręcz skraca się czas pracy i zamyka bibliotekę o północy lub wcześniej. Fakt, że $\mathrm{w}$ weekendy studenci zazwyczaj są mniej zainteresowani korzystaniem z biblioteki nocą sprawia, że w niektórych bibliotekach, w których po- 
stanowiono wprowadzić system całodobowego dostępu do biblioteki, zamiast pełnego obciążenia w systemie $24 / 7$ wprowadza się alternatywnie system $24 / 5$, a więc z pięcioma pełnymi dobami, ale bez weekendów. $\mathrm{W}$ praktyce polega to na tym, że biblioteka jest nieprzerwanie dostępna przez ponad 120 godzin, a najprostszą definicję tego systemu zaproponowali Mark Sanders i Chris Hodges, pisząc: "opening on sunday morning and not closing until friday night" (Sanders \& Hodges, 2014, p. 309). Jednak nie wszędzie dniem rozpoczynającym cykl całodobowy jest niedziela. Na przykład w Bibliotece Głównej University College London (UCL) system $24 / 5$ polega na tym, że ciąg pięciu dób zaczyna się $\mathrm{w}$ poniedziałek rano i kończy w sobotę wieczorem².

Choć więc coraz więcej bibliotek uczelnianych ustala dłuższe godziny pracy - zwłaszcza w okresach sesji egzaminacyjnych - nie można stwierdzić, że system 24-godzinny staje się powoli profesjonalnym standardem (Bowman, 2013, p. 217). Co więcej, nie ma też pewności, że taki system pracy $\mathrm{w}$ ogóle stanie się standardem, bo wprowadzany na próbę system pracy całodobowej może $\mathrm{w}$ niektórych ośrodkach okazać się pozbawiony organizacyjnego i ekonomicznego uzasadnienia, a w konsekwencji stać się tylko okresową nowinką. Nierzadkie są też sytuacje, gdy biblioteki skracają godziny pracy - nie tylko z powodów oszczędnościowych, ale również po stwierdzeniu, że nocne godziny otwarcia nie znajdują frekwencyjnego uzasadnienia.

W wypowiedziach dotyczących korzystania z bibliotek uczelnianych w nocy, jako jeden z kontrargumentów dla tych innowacji, pojawiają się czasem uwagi dotykające aspektu fizjologicznego pracy $\mathrm{w}$ godzinach nocnych. $Z$ tego wywodzi się czasem opinie mówiące, że jednym z zadań uczelni jest także wpojenie młodym ludziom nawyku pracy systematycznej, odpowiednio zaplanowanej i zorganizowanej, a wobec tego w zasadzie nie powinno się studentom stwarzać możliwości pracy w nocy. To bez wątpienia ważna kwestia, bo zaburzenie - zwłaszcza długotrwałe - polegające na wprowadzeniu arytmii do cyklu praca-odpoczynek powoduje negatywne skutki dla funkcjonowania organizmu i jego metabolizmu. Czynnikiem towarzyszącym, i również przynoszącym negatywne konsekwencje, może być niewłaściwe odżywianie się produktami zakupionymi w automatach i spożywanie większej ilości kawy lub napojów izotonicznych. Jednak to zagadnienie nie będzie w dalszej części artykułu rozwijane. Można bowiem przyjąć, że biblioteki uczelniane tylko ułatwiają studentom to, co i tak by praktykowali. Większość osób, które są czy były studentami przyzna zapewne, że okresowo tzw. zarywanie nocy jest wpisane - niezależnie od mód i epok - w tradycję życia studenckiego.

${ }^{2}$ University College London - Library Services - Opening hours: <https://www.ucl.ac.uk/library/ opening-hours> [dostęp: 22.07.2019]. 
W bibliotekach, w których próbne lub docelowe wydłużenie planu godzinowego na czas nocy poprzedza się wstępnymi analizami, przy ocenie skutków takich innowacji rozważa się najczęściej następujące kwestie:

- czy wydłużenie godzin pracy ma następować tylko w okresach sesji egzaminacyjnych, czy w określonych dniach także $w$ trakcie semestru?

- w jakich okresach wystarczającym rozwiązaniem jest zamykanie biblioteki o północy, a kiedy będzie uzasadnione wydłużenie godzin pracy do wczesnych godzin rannych; czy są okresy, kiedy biblioteka powinna pracować całodobowo?

- jak dalece w godzinach nocnych może zostać zmniejszony personel merytoryczny w porównaniu z godzinami pracy w ciągu dnia; czy funkcjonowanie biblioteki bez personelu bibliotecznego nie jest zbyt śmiałym rozwiązaniem?

- jak w godzinach nocnych zapewnić użytkownikom bezpieczeństwo, czy musi to oznaczać zwiększenie liczby pracowników ochrony?

- czy w porze nocnej mają być dostępne te same strefy, do których jest dostęp za dnia, czy też powinno się ograniczać dostęp do niektórych pięter i pomieszczeń?

- które ze świadczonych w ciągu dnia usług (np. wypożyczenia, wypożyczenia międzybiblioteczne, usługi reprograficzne, usługi informacyjne) mogą lub powinny być niedostępne w porze nocnej?

- jak wydłużenie godzin pracy wpłynie na ogólne koszty funkcjonowania biblioteki i jak duża liczba użytkowników będzie ekonomicznie uzasadniała pracę $\mathrm{w}$ nocy?

Przedstawione $\mathrm{w}$ artykule doświadczenia zagranicznych (zwłaszcza anglosaskich) bibliotek w kwestii nocnej obsługi użytkowników mogą ułatwić odpowiedź na postawione wyżej pytania.

\section{PRACA W NOCY ODPOWIEDZIĄ NA OCZEKIWANIA STUDENTÓW}

Władze uczelni i menedżerowie bibliotek, w których wprowadzono nocną obsługę użytkowników, bardzo często podkreślają że innowacje są odpowiedzią na postulaty zgłaszane przez samorząd i organizacje studenckie. Reagowanie na głosy użytkowników jest oczywiście chwalebne, jednak powinno się dokonywać po od powiedniej analizie oceniającej możliwości organizacyjne i finansowe biblioteki, a także potwierdzającej rzeczywiste zapotrzebowanie na nowe rozwiązanie. Zwłaszcza, że w praktyce może się okazać, iż efektem wprowadzenia postulowanych zmian jest niezbyt intensywne wykorzystanie zastosowanej innowacji. Takie właśnie umiarkowanie sceptyczne stanowisko wobec koncepcji całodobowego otwierania bibliotek akademickich zaprezentowała Susan Breakenridge z Campbell Library - Biblioteki Uniwersytetu Rowan w Glassboro w stanie New Jersey - pisząc: „Organizacje studenckie zwracają się do biblio- 
tek akademickich o wprowadzenie systemu 24/7, zwłaszcza w czasie sesji egzaminacyjnych. Ale tylko dlatego, że studenci myśla, że mogą z niego korzystać, co nie oznacza, że tak będzie" (Breakenridge, 2017). Ten sceptycyzm znajduje potwierdzenie w praktyce, a o stosunkowo niewielkim w rzeczywistości zainteresowaniu studentów systemem całodobowym w bibliotekach, czy to w pełnym wymiarze 24/7, czy zredukowanym do wersji 24/5, można się przekonać na dwa sposoby. Pierwszy i najbardziej miarodajny sposób, to pomiary liczebności użytkowników w kolejnych godzinach nocnych, pokazujące, że na granicy nocy i dnia, a więc około godziny 4:00-5:00, liczba osób korzystających z biblioteki spada nie tylko do najniższego poziomu wśród pomiarów z całej doby, ale bywa, że nawet prawie do zera. Drugi sposób potwierdzenia tej tezy, to przeprowadzenie wśród studentów odpowiedniego badania ankietowego.

Takie właśnie badanie ankietowe, które uwidoczniło chęć studentów do korzystania $\mathrm{z}$ biblioteki w późnych godzinach nocnych, ale niekoniecznie do rana, przeprowadzono wśród użytkowników Bizzell Library - Biblioteki Oklahoma University w miejscowości Norman. Co istotne, badanie w Bizzell Library przeprowadzono między godziną 22:00 a 2:00, a więc respondentami ankiety byli wyłącznie wieczorni i nocni użytkownicy, a można założyć, że właśnie w tej grupie przede wszystkim należałoby szukać ewentualnych zwolenników całodobowego otwarcia biblioteki. Tymczasem na pytanie o to, czy ówczesne godziny otwarcia biblioteki (od niedzieli do czwartku w godzinach 7:30-2:00) są odpowiednie, aż 82\% uczestników badania odpowiedziało twierdząco, a tylko $18 \%$ uznało taki wymiar godzinowy za niewystarczający (Engel, Womack \& Ellis, 2002, p. 103). Oznacza to, że zwolennicy całodobowego udostępniania przestrzeni bibliotecznej są w mniejszości, natomiast znacząca jest ta część studentów, którzy oczekuja że ich uczelniana biblioteka będzie dostępna do późnych godzin nocnych.

Zdarza się, że organizacje studenckie przedstawiają swoje oczekiwania odnośnie nocnej dostępności bibliotek w sposób bardziej zdecydowany niż forma memoriału do władz uczelni. Przykładem może być protest studentów irlandzkiego uniwersytetu w Cork (University College Cork - UCC), którzy w grudniu 2014 r. odmówili opuszczenia biblioteki uczelnianej w porze zamykania i pozostali $\mathrm{w}$ niej jeszcze przez dwie godziny. Wśród komentarzy towarzyszących temu wydarzeniu pojawiło się niepozbawione racji retoryczne pytanie: „Jaki jest sens mieć fantastyczną bibliotekę wartą miliony euro, skoro zamyka się ją o dziewiątej" (Ryan, 2014) ${ }^{3}$. Ale z polskiej perspektywy protest na Uniwersytecie w Cork musi budzić jednak pewną konsternację. Skoro bowiem zagraniczni studenci potrafią zorganizować protest przeciwko zbyt wczesnemu zamykaniu biblioteki

${ }^{3}$ Oryg.: What's the point in having a fantastic multi-million euro library if it closes at nine? 
uczelnianej w sytuacji, gdy ta zamykana jest o 21:00, to co mają powiedzieć studenci w polskich uczelniach, których biblioteki główne zamykane są już o 19:00 czy 20:00, a w czasie wakacji bywają w ogóle zamknięte?

Protesty studentów związane z godzinami pracy bibliotek są jeszcze bardziej zrozumiałe, kiedy są powodowane nie tyle brakiem odpowiedzi na postulaty wydłużenia godzin pracy biblioteki, co reakcją na decyzję o skróceniu czasu jej otwarcia. Można też stwierdzić, że tego rodzaju protesty mają już długą tradycję. Często wskazywanym w tym kontekście przykładem jest sytuacja z 1993 r. na Uniwersytecie Carnegie Mellon w Pittsburgu, gdzie podjęto decyzję o skróceniu godzin otwarcia biblioteki uczelnianej od poniedziałku do czwartku. Wcześniej w tych dniach tygodnia biblioteka była otwarta do 3:00 nad ranem. Ale personel biblioteki sygnalizował, że w początkowej części tygodnia bardzo niewielka grupa osób korzysta z biblioteki w późnych godzinach nocnych. Podjęto więc decyzję, że od poniedziałku do czwartku biblioteka będzie zamykana o północy. Argumentowano przy tym, że skrócenie godzin otwarcia biblioteki pozwoli na zaoszczędzenie $\mathrm{w}$ ciągu roku akademickiego ok. 15 tys. (ówczesnych!) dolarów. Jednocześnie powołano się na dane z automatycznego systemu kontroli wejść do biblioteki, z których wynikało, że tylko 3,5\% z ogólnej liczby użytkowników biblioteki odwiedzało ją po północy. Mimo tej argumentacji we wrześniu 1993 r. kilkudziesięciu studentów Uniwersytetu w Pittsburgu czterokrotnie zorganizowało akcję protestacyjną polegająca na odmowie opuszczenia biblioteki uczelnianej o północy (L.K., 1993).

Podobny protest miał też miejsce w 2013 r., a opisał go Ian Chant w „Library Journal”. Chodzi o Bibliotekę Uniwersytecką w Tampa na Florydzie, gdzie kilka lat temu wprowadzono system pracy 24/5, czyli pięć dni w tygodniu przez całą dobę. Ten sposób organizacji pracy biblioteki cieszył się dużym zainteresowaniem i akceptacją ze strony studentów. Przeciętnie o trzeciej nad ranem obserwowano ok. 400-600(!) studentów uczących się w bibliotece. Otwarcie biblioteki w godzinach nocnych było możliwe dzięki finansowemu wsparciu z Uczelnianego Biura Karier Studenckich, a koszt nowej formy usług był - jak twierdzi autor - wysoki i wynosił o 136 tys. USD więcej niż to miało miejsce w poprzednim systemie, gdy biblioteka była czynna tylko do północy. Podana kwota jest nominalnie duża, jeśli jednak przeliczy się tę dodatkową kwotę na jeden dzień (w zasadzie noc) pracy biblioteki, to wychodzi, że możliwość odwiedzenia biblioteki w nocy przez owych 400-600 studentów kosztowała uczelnię dodatkowo tylko ok. 500 USD dziennie. Jednak w wakacje 2013 r., ze względów oszczędnościowych, postanowiono wrócić do poprzedniego systemu pracy i ponownie ustalono, że biblioteka będzie zamykana o północy. To wywołało protest studentów Uniwersytetu Południowej Florydy, którzy po zamknięciu biblioteki koczowali w śpiworach pod jej 
budynkiem do rana, do momentu ponownego otwarcia. Ostatecznie władze uczelni i kierownictwo biblioteki ugięły się pod naciskiem studentów i jeszcze na jesieni 2013 r. przywrócono system 24/5, choć zasadniczo problem finansowy nie został rozwiązany (Chant, 2013, p.18).

\section{CZYNNIKI MAJĄCE WPŁYW NA DECYZJĘ O WYDŁUŻENIU GODZIN PRACY}

Niezależnie od faktycznych potrzeb i oczekiwań użytkowników w kwestii nocnego dostępu do biblioteki oraz przychylnego nastawienia kierownictwa biblioteki do tej innowacji, wprowadzenie trybu pracy nocnej zależy też od innych czynników. Wśród nich wymienić należy lokalizację biblioteki i jej przestrzenną organizację. Lokalizacja biblioteki, a szczególnie dostęp do środków komunikacji miejskiej, ma istotne znaczenie przy podejmowaniu decyzji o wydłużaniu godzin pracy i ewentualnej pracy w nocy. Dla osób, które chciałyby korzystać do późnych godzin nocnych z biblioteki, a nie dysponują własnym środkiem lokomocji, ma znaczenie kwestia możliwie łatwego i szybkiego skorzystania z komunikacji miejskiej - późnej dziennej lub nocnej. Zatem te biblioteki, które są dobrze skomunikowane, niezależnie od tego, czy znajdują się na terenie kampusu uczelnianego czy poza kampusem, mogą liczyć na odpowiednie zainteresowanie ich nocną ofertą. Przykładem polskiej biblioteki, której lokalizacja, z punktu widzenia dostępu do transportu miejskiego, jest satysfakcjonująca, może być Biblioteka Uniwersytecka w Warszawie. $Z$ jednej strony wciąż pozostają w pamięci dyskusje sprzed 20 lat na temat lokalizacji nowej biblioteki UW. Nie brakowało głosów uznających lokalizację na warszawskim Powiślu, z dala od kampusu przy Krakowskim Przedmieściu, za niezbyt fortunną. Początkowo też pewne decyzje Zarządu Transportu Miejskiego odnośnie komunikacji w pobliżu budynku nowej BUW nie były z punktu widzenia studentów i pracowników UW satysfakcjonujące. Jednak czas pokazał, że niegdysiejsze obawy przed umiejscowieniem Biblioteki „na uboczu” nie były zasadne, a dostęp do środków komunikacji miejskiej jest dziś umiarkowanie satysfakcjonujący. Po wyjściu z BUW w bezpośredniej bliskości budynku znajdują się bowiem przystanki komunikacji miejskiej w obu możliwych tam kierunkach, na których zatrzymują się także autobusy komunikacji nocnej. Z kolei przykładem biblioteki, gdzie jest to zdecydowanie utrudnione, może być druga biblioteka uniwersytecka w Warszawie - Biblioteka UKSW - która znajduje się prawie kilometr od najbliższego przystanku tramwajowego, a droga do niego wiedzie przez Las Bielański. W sytuacji ewentualnego uruchomienia nocnej obsługi studentów przez tę Bibliotekę perspektywa 15 minut nocnego spaceru przez ciemny las byłaby dla wielu niezmotoryzowanych użytkowników istotnym czynnikiem zniechęcającym. 
Jeśli chodzi o organizację przestrzenną biblioteki, to należy jeszcze raz przywołać jedno z pytań postawionych na wstępie artykułu. Chodzi o ustalenie, czy w porze nocnej użytkownicy mają mieć dostęp do tych samych części budynku biblioteki, z których korzystają w ciągu dnia, czy też przyjąć, że niektóre pomieszczenia biblioteki będą w nocy niedostępne. Na pewno łatwiej jest wprowadzić system otwarcia całodobowego $\mathrm{w}$ nowej bibliotece, której projekt $\mathrm{z}$ góry zakładał taką organizację, niż w starszym budynku, gdzie pomysł otwarcia całodobowego może być trudny do pogodzenia $z$ dotychczasową organizacją pracy i z istniejącymi rozwiązaniami przestrzennymi i technicznymi. W związku z tym, że organizacja nocnego dostępu do biblioteki zakłada znaczną samodzielność użytkowników (self service), wprowadzenie trybu pracy nocnej przychodzi łatwiej we współczesnych bibliotekach projektowanych z myślą wolnego dostępu do zbiorów. Ale nawet w takich bibliotekach zdarza się, że w porze nocnej ogranicza się użytkownikom możliwość swobodnego poruszania się po całej bibliotece. Powodem jest to, że w późnych godzinach wieczornych zmniejszony liczebnie personel ma mniejsze możliwości sprawowania kontroli nad wydarzeniami w bibliotece. Stosuje się więc niekiedy rozwiązanie polegające na zamykaniu dostępu do określonych przestrzeni, by osoby przebywające w budynku nie były rozproszone we wszystkich zakątkach biblioteki. Problem w tym, że w niektórych bibliotekach zastosowane rozwiązania architektoniczne nie dają specjalnie możliwości wyłączania fragmentów biblioteki dostępnych o normalnej porze dla użytkowników. Przykładem może być ponownie Biblioteka Uniwersytecka w Warszawie, w której trudno byłoby wyłączyć dostęp do pewnych przestrzeni. Paradoksalnie, najprościej byłoby zamknąć dostęp do czytelni głównej, bo to jedyna przestrzeń dla użytkowników BUW, którą w tradycyjnym rozumieniu można by określić jako „salę biblioteczną" (reading room). Ale przecież takie zamknięcie mijałoby się z celem. Pozostałych przestrzeni BUW, po których swobodnie poruszają się studenci, nie da się praktycznie w prosty i szybki sposób zamknąć, bo tam nie ma sal. Zatem ze względu na rozwiązania architektoniczne ta przestrzeń w BUW, po której użytkownicy poruszają się swobodnie w ciągu dnia, pozostaje dostępna także w nocy.

Są jednak biblioteki, w których zastosowane rozwiązania architektoniczne ułatwiają podjęcie decyzji o ograniczeniu w godzinach nocnych dostępu do niektórych przestrzeni w bibliotece. Przykładowe rozwiązanie tego typu przedstawili Mark Sanders i Chris Hodges opisujący organizację pracy nocnej w głównej bibliotece Uniwersytetu Karoliny Wschodniej (ECU) w Greenville, NC. Z opisu wynika mianowicie (a przynajmniej tak było jeszcze w 2014 r.), że dla większego bezpieczeństwa o godzinie 2:00 w nocy strażnicy zamykają dostęp do trzech z czterech poziomów biblio- 
teki ${ }^{4}$, a na pierwszym poziomie, który wciąż pozostaje dostępny, dokonuje się kontroli legitymacji studenckich i pracowniczych, by potwierdzić, że o tej porze wśród użytkowników biblioteki nie ma już osób spoza uczelni, które mogły wejść do Biblioteki przed 23:00 (Sanders \& Hodges, 2014, p. 313). Jednak ze szczegółowego planu biblioteki wynika, że zasadnicze zbiory biblioteczne znajdują się akurat na poziomach, które po godzinie 2:00 są zamykane, natomiast na poziomie pierwszym, wciąż o tej porze dostępnym, znajdują się m.in. stanowiska do pracy indywidualnej z wyposażeniem komputerowym, sale do pracy grupowej, a także automaty z produktami spożywczymi i kawiarnia. A to znaczy, że przestrzeń dostępna po godzinie 2:00 ma ograniczoną funkcję biblioteczną i pełni przede wszystkim funkcję miejsca do nauki, więc bardziej zasługuje na alternatywne określenie „learning space" lub „learning commons" niźli na miano biblioteki.

\section{DODATKOWE KOSZTY NOCNEJ DOSTĘPNOŚCI BIBLIOTEK}

Otwarcie biblioteki w porze nocnej wydaje się dużym wyzwaniem nie tylko organizacyjnym, ale też finansowym. Wszak praca w godzinach dodatkowych i jeszcze do tego nocnych wymagałaby odpowiedniego dodatkowego wynagrodzenia. Zatem można przyjąć, że obok podstawowego kosztu prowadzenia biblioteki, jakim jest fundusz wynagrodzeń i świadczeń dla pracowników, biblioteka musiałaby uwzględnić ekstra wynagrodzenie za pracę $\mathrm{w}$ godzinach niestandardowych. Tymczasem wcale tak być nie musi i przedłużanie pracy biblioteki do późnych godzin nocnych, a nawet na całą noc, pod pewnymi warunkami nie musi oznaczać poniesienia dużo wyższych kosztów. Jak bowiem twierdzi Simon Francis, doświadczenia brytyjskich bibliotek uczelnianych pokazują że wydłużony czas pracy biblioteki akademickiej w godzinach nocnych jest rozwiązaniem stosunkowo tanim, o ile ograniczy się liczbę osób obecnych w bibliotece $\mathrm{w}$ tych godzinach, a także jeśli do pracy w nocy zaangażuje się tylko pomocniczy personel biblioteki, a nawet tylko ochronę (Francis, 2009, s. 123). Biblioteka musi jednak oferować w znacznym stopniu wolny dostęp do zbiorów i stworzyć użytkownikowi warunki do wykazania się daleko idącą samodzielnością. Wtedy liczbę personelu można istotnie zmniejszyć, a niezbędną, mimo wszystko, kontrolę sprawować nawet ograniczając się do dyskretnej obserwacji okiem kamery.

\footnotetext{
${ }^{4}$ Szczegółowy plan Biblioteki ECU (Joyner Library - Floor Maps: <https://library.ecu.edu/about/ floor-maps/) podaje, że tych poziomów jest faktycznie pięć.
} 


\section{TRYB BEZOBSŁUGOWY I SAMOOBSŁUGA A KWESTIA BEZPIECZEŃSTWA}

W rozstrzyganiu kwestii przedłużania godzin pracy bibliotek akademickich na porę nocną panuje zatem zgodne przekonanie, że będzie to organizacyjnie możliwe i ekonomicznie uzasadnione tylko przy zmniejszonym personelu i ograniczonej funkcjonalności biblioteki wymuszającej większą samodzielność użytkowników (self service). O ile jednak łatwiej jest zaakceptować rozwiązanie polegające na znacznym ograniczeniu obecności personelu bibliotecznego, a nawet jego całkowitej nieobecności (unstaffed), o tyle jakiekolwiek zmniejszenie zespołu pracowników ochrony musi rodzić pytania o bezpieczeństwo użytkowników i zbiorów. Przyjmuje się więc nie bez racji, że w porze nocnej niektóre działy i pracownie biblioteki mogą nie funkcjonować, a w pierwszym rzędzie wymienia się tu wypożyczalnię i obsługę zamówień z magazynu do czytelni. Skoro więc nocne korzystanie z biblioteki ogranicza się praktycznie do wolnego dostępu do zbiorów, komputerów, drukarek, kserokopiarek i skanerów, to łatwo wyobrazić sobie ograniczenie personelu bibliotecznego do dwóch-trzech osób w czytelni i informatorium, a nawet zupełną nieobecność pracowników z tej grupy. Jednak ewentualne zmniejszenie liczby pracowników ochrony jest już poważniejszą decyzja, bo może się okazać, że zbyt mały zespół dyżurujących w nocy pracowników, odpowiadających za bezpieczeństwo budynku i osób w nim przebywających, może nie zaradzić w sytuacji zagrożenia. Z lektury publikacji opisujących biblioteki akademickie otwarte w nocy wynika co prawda pozytywny wniosek, że wbrew obawom w porze nocnejnienotuje się poważniejszych incydentów, a ochrona rzadko zmuszana jest do bardziej zdecydowanych interwencji. Jednak nie powinno to prowadzić do wniosku, że zespół pracowników ochrony, podobnie jak personel biblioteczny, może być w porze nocnej znacząco zmniejszony. Przeciwnie, nocni użytkownicy powinni mieć świadomość, że mimo ograniczonej funkcjonalności biblioteki jej wnętrze i część zewnętrzna są pod stałą kontrolą strażników i rejestrujących wszystko kamer.

\section{KORZYSTANIE Z BIBLIOTEK W NOCY - POMIARY I BADANIA ANKIETOWE}

Zjawiskiem spodziewanym i potwierdzanym we wszystkich analizach wykorzystania bibliotek w nocy jest postępujący z każdą godziną znaczący spadek liczby osób przebywających w bibliotece po północy. Ubytek użytkowników w kolejnych godzinach nocnych jest powtarzalny i oznacza, że przeciętnie między północą a 3:00 w nocy liczba użytkowników zmniejsza się o ponad połowę i w podobnej wielkości następuje to między godziną 3:00 a 6:00 rano. Szczegółowych danych w tym zakresie 
dostarczyły np. pomiary liczby użytkowników nocnych przeprowadzone w 2014 r. w Bibliotece Uniwersytetu Rowan w Glassboro w stanie New Jersey, zarówno w okresie wiosennym, jak i jesienią. Wiosna, niezależnie od dnia tygodnia, tempo spadku liczby osób korzystających w nocy z biblioteki jest powtarzalne i wynosi w kolejnych godzinach między godziną 24:00 a 3:00 średnio $68 \%$, natomiast między godziną 3:00 a godziną 6:00 rano spadek wynosi kolejne $62 \%$. To ostatecznie oznacza, że ze średniej liczby, wynoszącej ok. 210 użytkowników obecnych w bibliotece o północy, o świcie pozostaje ich stosunkowo niewielka liczba, wynosząca średnio dla poszczególnych dni tygodnia 18 osób. To zaś oznacza przeciętnie 12-krotny spadek liczby użytkowników obecnych w bibliotece nad ranem w stosunku do ich liczby notowanej o północy (Breakenridge, 2017)5.

Zbliżone wyniki pomiarów spadku liczby użytkowników w kolejnych godzinach nocnych do wyników uzyskanych w badaniach Uniwersytetu Rowan w New Jersey zanotowano też w podobnych analizach przeprowadzonych w Bibliotece Appalachian State University w mieście Boone w Północnej Karolinie. Z pomiarów dokonywanych w semestrze zaczynającym się na jesieni 2014 r. wynikało, że liczba studentów korzystających z biblioteki o północy w czasie sesji kończącej semestr była dwa razy większa od ich liczby na początku semestru. Co więcej, spadek liczby korzystających z biblioteki w ciągu nocy był wyraźnie większy na początku semestru niż w trakcie sesji. Otóż w początkowej części semestru między godziną 24:00 a 3:00 w nocy liczba korzystających z biblioteki spadała o $88 \%$, a między godziną 3:00 a 6:00 o kolejne $47 \%$. Natomiast w okresie sesji tempo ubywania użytkowników słabło, bo między godziną 24:00 a 3:00 liczba korzystających z biblioteki zmniejszała się o około $76 \%$, a między 3:00 a 6:00 o 55\%, przy czym liczba osób przebywających w bibliotece o 6:00 rano była w okresie sesji średnio cztery razy większa niż o tej samej porze na początku semestru (Johnson \& McCallister, 2015, p. 81). Te dane pokazuja, że potrzeba korzystania z biblioteki w porze nocnej jest wyraźnie większa w czasie sesji niż na początku semestru i jednocześnie wynika $\mathrm{z}$ nich, że czas spędzony w bibliotece w godzinach nocnych będzie w czasie sesji egzaminacyjnych w przeliczeniu na użytkownika, znacząco dłuższy niż we wcześniejszych fazach semestru.

Podobnie prezentują się wyniki pomiarów dokonanych w Bibliotece Uniwersytetu Santa Clara w Kalifornii. Tak jak w innych bibliotekach akademickich notuje się tu duży spadek liczby osób korzystających z biblioteki w kolejnych godzinach nocnych. Uśrednione wyniki pomiarów

${ }^{5}$ Pomiary jesienne w Bibliotece Rowan University dały podobne wyniki. Między godz. 24:00 a 3:00 w nocy, spadek liczby użytkowników wynosił średnio 60\%, a między 3:00 a 6:00 rano średni spadek liczby użytkowników wynosił kolejne 69\% (Breakenridge, 2017). 
w kolejnych kwartałach roku akademickiego $2015^{6}$ pokazuja że liczba użytkowników korzystających z biblioteki tuż po północy wynosiła średnio 233 osoby, ale po godzinie 2:00 spadała już do poziomu 82 osób. Po godzinie 4:00 pozostawały w bibliotece 34 osoby, zaś po 6:00 było już tylko 19 użytkowników (Chrzastowski \& Nutefall, 2016, p. 186). Wynika z tego zatem, że średnia liczba użytkowników o godzinie 6:00 stanowiła tylko $8 \%$ liczby użytkowników o północy.

Powyższe obserwacje potwierdziły też dane zaprezentowane przez Sarę Laaker, a uzyskane podczas pomiarów korzystania w nocy z Biblioteki Uniwersytetu Waszyngtona w St. Louis w stanie Missouri. Pomiary kwietniowe, a więc w zwykłym okresie roku akademickiego, oraz w maju, czyli w trakcie sesji egzaminacyjnej potwierdziły, że znacząco spada liczba studentów obecnych w bibliotece $\mathrm{w}$ kolejnych godzinach pracy nocnej. Oto dwa przykładowe zestawienia z pomiarów kwietniowych, gdy biblioteka była otwarta do godziny 2:00:

$-\mathrm{w}$ nocy z poniedziałku na wtorek o 23:00 w bibliotece przebywały 223 osoby, o 24:00 - 173 osoby, o 1:00 w nocy 110 osób, a o 2:00 już tylko 15,

- w nocy z niedzieli na poniedziałek o 23:00 w bibliotece było 147 osób, o 24:00 - 104 osoby, o 1:00 w nocy 70 osób, a o 2:00 tylko 4 (Laaker, 2011, p. 20).

Spadek jest ewidentny, ale do podanych wyników można mieć drobne zastrzeżenie metodologiczne. Wskaźniki uzyskane podczas pomiarów dokonywanych o godzinie, w której następuje planowe zamknięcie biblioteki, mogą być bowiem mylące. $Z$ niskich liczb wówczas notowanych nie wynika przecież, że dlatego o godzinie 2:00 w nocy w bibliotece pozostawało tylko kilka osób, bo pozostali, którzy już bibliotekę opuścili, nie mieli sił lub ochoty, by wciąż z niej korzystać. Można bowiem założyć, że ochotę do dalszej pracy mieliby, ale wyszli z powodu spodziewanej godziny zamknięcia. Normalnym bowiem zjawiskiem jest systematyczne opuszczanie biblioteki przez użytkowników w czasie, gdy zbliża się planowa godzina zamknięcia, a nie w ostatniej chwili. Za bardziej miarodajne, $\mathrm{w}$ ocenie zapotrzebowania na korzystanie $\mathrm{z}$ biblioteki, należałoby więc uznać wyniki uzyskiwane przynajmniej na godzinę przed planowym zamknięciem. A te wskaźniki w Bibliotece w St. Louis nie były niskie. Podczas pomiarów kwietniowych liczba studentów pozostających w bibliotece o godzinie 1:00 była przeciętnie dwukrotnie niższa względem liczby notowanej o godzinie 23:00, jednak nie była bardzo niska i średnio wynosiła ok. 80 osób. To nie jest wskaźnik aż tak niski, by postawić pytanie o sens ekonomiczny utrzymywania dostępności biblioteki o tak późnej porze.

\footnotetext{
${ }^{6}$ Chodzi o praktykowany w niektórych uczelniach kwartalny, a nie semestralny podział roku akademickiego.
} 
Podczas pomiarów majowych, a więc w czasie ożywienia egzaminacyjnego, gdy biblioteka wydłużała pracę do 4:00 nad ranem, potwierdziły się przypuszczenia, że w tym okresie większa liczba studentów będzie skłonna pozostać $\mathrm{w}$ bibliotece $\mathrm{w}$ porze nocnej przez dłuższy czas. Największą liczbę studentów korzystających z biblioteki w środku nocy, zanotowano $\mathrm{z}$ niedzieli na poniedziałek, gdy o godzinie 1:00 było $\mathrm{w}$ bibliotece 210 użytkowników, o 3:00 ich liczba zmniejszyła się do 79 osób, a o 4:00 pozostał w bibliotece tylko jeden student (Laaker, 2011, p. 21). W sumie we wszystkich pomiarach majowych okazywało się, że o godzinie 3:00 nad ranem w bibliotece znajdowało się dwa-trzy razy mniej użytkowników względem ich liczby notowanej o godzinie 1:00, co jednak obiektywnie nie było liczbą małą. Z pomiarów dokonywanych w głównej bibliotece Uniwersytetu Waszyngtona w St. Louis nie wynikało zatem, żeby biblioteka w godzinach nocnych w sposób wyraźny pustoszała, a bardzo mała liczba osób opuszczających bibliotekę w momencie jej zamykania mogła wynikać z sukcesywnego jej opuszczania przez użytkowników w miarę, jak zbliżała się godzina zamknięcia.

Pomiary i badania w Bibliotece Uniwersytetu Waszyngtona w St. Louis uwidoczniły jeszcze jeden interesujący aspekt otwierania bibliotek uczelnianych w nocy. Okazało się mianowicie, że wśród zwolenników nocnego dostępu do biblioteki wcale nie przeważają studenci wyższych lat studiów, którzy finalizują studia i przygotowują dysertacje, ale studenci niższych lat. Ankietowanym zadano mianowicie pytanie o to, co oprócz gromadzenia zbiorów mogłaby biblioteka uczelniana zaoferować swoim użytkownikom. O ile studenci studiów magisterskich (graduate) wśród 10 możliwych odpowiedzi dopiero na szóstej pozycji stawiali możliwość otwarcia biblioteki w nocy, to wśród studentów studiów licencjackich (undergraduate), ta opcja zajęła wysokie drugie miejsce (Laaker, 2011, p. 16).

Przeprowadzone w St. Louis badania miały miejsce w 2011 r. Chęć korzystania z przestrzeni bibliotecznej w późnych godzinach nocnych i nad ranem przez znaczącą liczbę studentów ewidentnie przekonała władze uczelni do wydłużenia godzin otwarcia biblioteki. W tym samym roku postanowiono, na okres próbny, wprowadzić system pracy 24/4, dziś zaś Biblioteka Główna Uniwersytetu w St. Louis i w kwietniu, i w maju pracuje w systemie 24/7, co można sprawdzić z kilkutygodniowym wyprzedzeniem $\mathrm{w}$ interaktywnym kalendarzu działającym na stronie Biblioteki ${ }^{7}$.

Tu warto zauważyć, że takie interaktywne kalendarze można znaleźć na wielu stronach zagranicznych bibliotek uczelnianych, co świadczy o dużej dbałości o wygodę użytkownika. Każdy zainteresowany może bowiem z użyciem takiego narzędzia sprawdzić nawet z kilkumiesięcznym wyprze-

${ }^{7}$ Washington University in St. Louis - Olin Library Hours: <https://library.wustl.edu/units/olinlibrary/olin-library-hours/> [dostęp: 22.07.2019]. 
dzeniem, jak będzie dostępna biblioteka uczelniana w określonym dniu roku akademickiego. Na przykład już latem 2019 r. na stronie Library West - biblioteki University of Florida - można było sprawdzić, że w kwietniu $2020 \mathrm{r}$. Biblioteka będzie otwarta 24 godziny przez wszystkie $30 \mathrm{dni}^{8}$.

\section{PRACA W NOCY W NIEKTÓRE DNI TYGODNIA?}

Dodatkową informacją wynikającą ze wspomnianych wcześniej pomiarów przeprowadzonych w Bibliotece Rowan University, a istotną dla bibliotek różnicujących godziny otwarcia w zależności od dni tygodnia, jest swego rodzaju ranking tygodniowy mówiący o korzystaniu z biblioteki w jego kolejnych dniach. Otóż ten ranking, bez zagłębiania się we wskazania szczegółowe, przedstawia się następująco: wtorek, środa, poniedziałek, czwartek, niedziela, piątek i sobota. Oznacza to, że we wtorek i w środę, w kolejnych porach dnia, w bibliotece przebywa najwięcej użytkowników. Ostatnia w tym zestawieniu pozycja soboty może być zrozumiała, co tłumaczy się głównie weekendowym życiem towarzyskim studentów. Z wykresów godzinowych wynika bowiem, że w piątek po południu, gdy nadchodzi pora spotkań, zaczyna szybko spadać liczba osób obecnych w bibliotece. W sobotę natomiast ci najszybciej zregenerowani użytkownicy oraz ci, którzy w piątkowym życiu towarzyskim nie brali udziału, pojawiają się w bibliotece w większej liczbie dopiero wczesnym popołudniem, choć i tak jest to liczba wyraźnie mniejsza w porównaniu $\mathrm{z}$ tą samą porą w piątek. Co więcej, wyniki odwiedzin zanotowane przez bibliotekę $\mathrm{w}$ soboty są znacząco niższe $\mathrm{w}$ porównaniu $\mathrm{z}$ innymi dniami tygodnia. W porównaniu z wtorkiem czy środą w sobotę o tej samej porze przebywa w bibliotece pięć-sześć razy mniej osób. Pewnym zaskoczeniem we wspomnianym rankingu może być też wyraźnie wyższa w porównaniu z piątkiem i sobotą (gdy spojrzeć na konkretne liczby odwiedzających) pozycja niedzieli. Z pomiarów dokonywanych w Campbell Library w Rowan University w maju 2015 r. wynikało, że liczba osób korzystających $\mathrm{z}$ biblioteki $\mathrm{w}$ niedzielę $\mathrm{w}$ godzinach wieczornych była cztery-pięć razy większa w porównaniu z liczbą odwiedzających zanotowaną o tej samej porze $\mathrm{w}$ sobotę (Breakenridge, 2017). Może to być jednak zrozumiałe, gdyż potrzeba korzystania $\mathrm{z}$ biblioteki w niedzielę nasila się $\mathrm{w}$ miarę zbliżania się poniedziałkowych zajęć lub egzaminów. W piątkowy i sobotni wieczór ta presja jeszcze tak silnie nie występuje.

Wspomniane wcześniej badanie przeprowadzone w Bizzell Library w Oklahoma University również pozwoliło wyciągnąć wnioski w kwestii większej popularności nocnej dostępności biblioteki w określonych dniach tygodnia. Potwierdziło się zatem, że użytkownicy, którzy mają ${ }^{8}$ University of Florida - UF Library Hours: <http://www.uflib.ufl.edu/ps/hours/> [dostęp: 22.07.
2019]. 
zwyczaj korzystania z biblioteki w godzinach wieczornych i późnych nocnych, najczęściej robią to od poniedziałku do środy. Zrozumiałe jest, że intensywność korzystania z biblioteki uczelnianej w wieczory weekendowe jest mniejsza, zwraca jednak uwagę, że zmniejszone zainteresowanie korzystaniem z Bizzell Library notuje się nie od piątku, ale także w wieczór czwartkowy. Tłumaczy się to tym, że część studentów ma zwyczaj zaczynać weekend już w czwartek (Engel, Womack \& Ellis, 2002, p. 103).

\section{NOCNI UŻYTKOWNICY W BIBLIOTECE - WĄTPLIWOŚCI I OBAWY}

Znikoma liczebność użytkowników bibliotek na granicy nocy i dnia, skłania do postawienia pytania o zasadność wprowadzania nie tylko systemu pracy całodobowej, ale nawet wydłużania czasu pracy znacząco po północy. Musi się bowiem pojawić wątpliwość i pytanie, czy jest ekonomicznie uzasadnione utrzymywanie dużej biblioteki akademickiej w gotowości do przyjęcia użytkowników o godzinie 5:00-6:00 nad ranem, skoro faktycznie liczba osób korzystających o tej porze z biblioteki zdecydowanie spada. Nawet jeśli biblioteka działa w trybie bezobsługowym, a więc bez bibliotekarzy w czytelniach, wypożyczalni i informatorium, to jednak ponosi się koszty utrzymywania zespołu pracowników ochrony, oświetlenia budynku i zasilania wszelkich urządzeń potrzebnych do sprawnego, wygodnego i bezpiecznego funkcjonowania książnicy. Czy więc mała, a czasem bliska zeru liczba użytkowników biblioteki w późnych godzinach nocnych lub nad ranem nie jest argumentem za tym, by jednak nie ponosić kosztów otwierania bibliotek o nietypowych porach, gdy biblioteka może, ale nie musi być otwarta?

W publikacjach dotyczących przedłużania czasu pracy na godziny nocne autorzy przyznają również, że w bibliotekach, w których analizowano taką potrzebę, pojawiały się wątpliwości, czy biblioteka nie będzie w godzinach nocnych wykorzystywana przez studentów bardziej do spotkań towarzyskich lub po prostu do spania. Tych obaw nie potwierdziły wspomniane już badania przeprowadzone w Bibliotece Appalachian State University w Boone. Analiza rodzajów aktywności studentów Appalachian State University nocą w bibliotece wykazała, że ich zdecydowana większość (96\%) skupia się na korzystaniu z komputerów i studiowaniu, a tylko 3\% użytkowników biblioteki uczestniczy w jakichś formach socjalizacyjnych. Pozostały 1\% użytkowników zaliczony został do kategorii "śpiący" (Johnson \& McCallister, 2015, p. 81).

Przy ocenie spodziewanych skutków nocnego otwarcia biblioteki pojawiają się też obawy, czy rano studenci nie pozostawią w bibliotece resztek jedzenia i ogólnego nieporządku. W praktyce - jak przyznają Peg Lawrence i Lynne Weber - takie obawy okazują się najczęściej bezpodstawne („groundless"), a w sprawozdaniach dotyczących pracy w nocy odnoto- 
wuje się nieliczne zachowania odbiegające od przyjętych norm (Lawrence \& Weber, p. 529; Johnson \& McCallister, p. 82).

$\mathrm{W}$ badaniu przeprowadzonym $\mathrm{w}$ McLaughlin Library - bibliotece uniwersyteckiej w kanadyjskim mieście Guelph (Ontario) - również jako jeden $\mathrm{z}$ analizowanych problemów pojawiła się kwestia ewentualnego wykorzystywania biblioteki otwartej w nocy do spotkań towarzyskich. W analizie danych pomiarowych zastosowano więc podział na użytkowników indywidualnych, a także na pracujących w parach oraz w grupach. To słuszne podejście, bo choć organizacja przestrzeni bibliotecznej i zasady obowiązujące zwłaszcza w czytelniach sprzyjają zasadniczo pracy indywidualnej, to jednak można bardzo często zauważyć w bibliotekach pary osób albo grupy kilkuosobowe, które podczas pobytu w bibliotece ewidentnie spędzają ze sobą czas, nawet jeśli nie realizują wspólnie jakiegoś zadania. W Guelph stwierdzono zatem, że w nocy obecność w bibliotece grup studentów wcale nie oznacza wspólnej pracy nad jakimś projektem. Właściwie studenci pracują we własnym zakresie, a obecność grup świadczy tylko o potrzebie wspólnotowości i utrzymywania więzi z rówieśnikami i znajomymi (Dol et. al., 2012, p. 6).

Podobnie jak z innych badań, także z tych wynikało, że ok. północy opuszcza bibliotekę większa część studentów (oryg.: The exodus happens around midnight) (Dol et. al., 2012, p. 4). Istotnie wpływa na to fakt, że około północy odjeżdżają ostatnie dzienne autobusy. Zauważono jednocześnie, że w sposób znaczący spada o tej porze liczba pojedynczych dziewcząt (Dol et. al., 2012, p. 4, 6). Obecność kobiet jest w ogóle jednym z ciekawszych zagadnień interesujących osoby zajmujące się analizą wykorzystania bibliotek w nocy. Z badań mianowicie wynika, że wśród nocnych użytkowników bibliotek akademickich nieznacznie przeważają mężczyźni. Nawet wtedy, gdy ogólny odsetek kobiet w uczelni jest wyższy niż odsetek mężczyzn. Pokazują to np. wyniki badań przeprowadzonych w Bibliotece Uniwersytetu Santa Clara w Kalifornii, gdzie okazało się, że $59 \%$ nocnych użytkowników biblioteki stanowili mężczyźni, a 41\% kobiety. Mimo że z danych ogólnouczelnianych wynikała lekka przewaga kobiet, które stanowiły 51\% ogólnej liczby studentów (Chrzastowski \& Nutefall, 2016, p. 185). Jeszcze większą przewagę mężczyzn wśród nocnych użytkowników bibliotek akademickich odnotowano w Valley Library Bibliotece Uniwersytetu Stanu Oregon (OSU). Jak podają autorzy badania, w uczelni tej stosunek liczby studiujących mężczyzn do liczby kobiet jest zbliżony do proporcji 50:50. Tymczasem według statystyki użytkowania biblioteki OSU w nocy ten stosunek wynosi przeciętnie 67:33 na korzyść mężczyzn (Sowell \& Nutefall, 2014, p. 104). Nadreprezentatywność mężczyzn wśród nocnych użytkowników bibliotek nie jest jednak zaskoczeniem. W wielu publikacjach powtarzają się co prawda uwagi o braku poważniejszych incydentów i naruszeń regulaminu podczas nocnej pracy 
biblioteki, co pozwala na stwierdzenie, że biblioteki otwarte $\mathrm{w}$ nocy są miejscami tak samo bezpiecznymi, jak za dnia. Jednak widać pora nocna, postrzegana jako ten mniej bezpieczny czas w ciągu doby, sprawia, że niektóre studentki - same lub pod wpływem rodziców - rezygnują z nocnej wyprawy do biblioteki.

\section{GODZINA 2:00 W NOCY - OPTYMALNE ROZWIĄZANIE?}

Z obserwacji dokonywanych w różnych bibliotekach wynika, że okolice godziny 2:00 w nocy, to czas, gdy już w sposób wyraźny zaczyna zmniejszać się liczba użytkowników przebywających w bibliotece. Na przykład z wywiadów przeprowadzonych przez Adama C. Bowmana z przedstawicielami bibliotek prowadzących obsługę całodobową wynika, że większość bibliotek po godzinie 2:00 w nocy obserwuje znaczący spadek liczby użytkowników („dramatic decline in patron numbers”) (Bowman, 2013, p. 233). Jest to spodziewane i naturalne, bo nawet osoby, które $\mathrm{w}$ fazę większej aktywności i wydajności wchodzą po południu i wieczorami, też w pewnym momencie muszą odczuć znużenie i wejść w fazę kryzysu. Wydaje się, że właśnie godzina 2:00 jest tym momentem, gdy "sowy” podejmują decyzję, że czas odpocząć. Z tego względu w niektórych bibliotekach uczelnianych, które nie pracują całodobowo, ale w okresach sesji egzaminacyjnych wydłużają czas otwarcia, często właśnie godzinę 2:00 w nocy ustala się jako moment zamknięcia biblioteki. Przykładem może być Library Learning Centre na Politechnice w Delft (Technische Universiteit Delft) w Holandii. Jak podaje strona internetowa Biblioteki, jest ona otwarta 365 dni w roku, również w święta narodowe. W zwykłych okresach pracuje $\mathrm{w}$ godzinach 8:00-24:00, ale $\mathrm{w}$ czasie sierpniowej sesji egzaminacyjnej wydłuża czas dostępu właśnie do godziny 2:009.

Obserwowany w wielu bibliotekach spadek liczby użytkowników ok. 2:00 w nocy sprawia, że jednym z praktykowanych i efektywnych systemów podziału tygodniowego czasu pracy jest system, w którym od poniedziałku do czwartku biblioteka jest dostępna do 2:00, a od piątku do niedzieli pracuje kilka godzin krócej. Przykładem wdrożenia takiego systemu może być Biblioteka Główna Uniwersytetu w Denver, Colorado - Anderson Academic Commons. Tylko 20 dni w roku (według planu na okres od czerwca 2019 do czerwca 2020) Biblioteka jest dostępna przez 24 godziny, natomiast najczęściej w dni powszednie otwarta jest od 7:00 rano do 2:00 w nocy.

Anderson Academic Commons w Denver University jest więc przykładem biblioteki, która po analizie funkcjonalności zdecydowała się odejść

${ }_{9}^{9}$ TU Delft - Opening times Library Learning Centre: <https://www.tudelft.nl/en/library/usingthe-library/opening-times-locations/library-learning-centre/> [dostęp: 22.07.2019]. 
od wcześniej obowiązującego systemu 24/5 i skracając dobowy czas pracy przyjąć rozwiązanie bardziej uzasadnione ekonomicznie i organizacyjnie. Jak bowiem wynika z artykułu Bethany B. Sewell, w 2011 r. Biblioteka Uniwersytetu w Denver (wówczas pod nazwą Penrose Library) początkowo w sposób znaczący zwiększyła godzinową dostępność, przyjmując plan pracy $\mathrm{z}$ pięcioma dniami w tygodniu, w których gmach otwarty był non stop. W skali roku oznaczało to skok z poziomu 2469 godzin pracy do poziomu aż 7290 godzin (Sewell, 2013, p. 15). Jednak takie rozwiązanie okazało się nietrwałe i dziś system pracy Biblioteki Uniwersytetu w Denver można by w uproszczeniu określić jako $19 / 5$ zamiast $24 / 5^{10}$.

Takie redukcje $\mathrm{w}$ bibliotekach, które próbowały wprowadzić dłuższe godziny pracy, ale ostatecznie się z tego wycofały, zdarzają się częściej. Na przykład w 2015 r. Sherman Fairchild Library w California Institute of Technology skróciła godziny otwarcia i przeszła z systemu 24/7 na bardziej uzasadniony i mniej kosztowny system 24/5 (Davis, Liu \& Zhu, 2017, p. 1).

\section{SYSTEM CAŁODOBOWY, ALE NIE CAŁOROCZNY}

Jeszcze dekadę temu mogło się wydawać, że system 24-godzinnej dostępności będzie wprowadzać coraz więcej bibliotek akademickich w USA, a wynikało to z kolejnych raportów amerykańskiego Instytutu Badań Edukacyjnych Narodowego Centrum Statystyki Edukacyjnej (IES NCES) działającego przy Departamencie Edukacji USA. Z podsumowania tych danych za lata 1998-2008, opracowanego przez Denise M. Davis, wynikało, że w czasie tej dekady o 65\% zwiększyła się liczba bibliotek otwartych przez 168 godzin w tygodniu, czyli 24 godziny każdego dnia (Davis, 2011, p. 20). Procentowo był to wzrost znaczący, choć rzeczywiste liczby nie były wysokie. Faktycznie bowiem bibliotek akademickich otwartych non stop w 1998 r. raport IES NCES wykazywał 20, natomiast w 2008 r. było ich 33. Wkrótce jednak okazało się, że ten wzrost został przyhamowany, a nawet nastapił pewien regres. Oto bowiem według dwóch ostatnich raportów przygotowanych przez IES NCES ${ }^{11}$, a dotyczących działalności bibliotek akademickich, liczba amerykańskich bibliotek uczelnianych otwartych siedem dni w tygodniu przez 24 godziny odrobinę się zmniejszyła. W raporcie z 2011 r. (dane za 2010 r.) widniała liczba 32 bibliotek otwartych przez pełne 168 godzin (Academic Libraries, 2010, p. 5), natomiast w raporcie z 2014 r. (dane z 2012 r.) takich bibliotek było 31 (Academic Libraries, 2012, p. 5).

\footnotetext{
${ }^{10}$ University of Denver - University Libraries - Hours: <https://ibrary.du.edu/media/documents/ year-calendar.pdf $>$ [dostęp: 22.07.2019].

${ }^{11}$ Od 2014 r. dane na temat bibliotek akademickich gromadzi Zintegrowany System Danych Edukacyjnych IPEDS (Integrated Postsecondary Education Data System - https://nces.ed.gov/ipeds/).
} 
Warto jednak przyjrzeć się tym liczbom bliżej, bo dane szczegółowe pokazują że ten niewielki spadek wynika właściwie ze zmniejszenia się liczby bibliotek akademickich otwartych całą dobę $w$ uczelniach utrzymywanych ze środków publicznych (spadek z 15 w 2010 do 12 w 2012 r.), bo akurat w uczelniach prywatnych nastąpił lekki wzrost (z 17 w 2010 do 19 w 2012 r.). Statystycznie są to zmiany drobne, jednak pozwalają wysnuć ogólny wniosek, że systemu 24/7 nie można jeszcze określać mianem trendu. Należy jednak pamiętać, że podane liczby odnoszą się do tzw. przeciętnego tygodnia pracy biblioteki (typical week), co oznacza, że liczba bibliotek w ogóle w jakimś stopniu praktykujących system 24/7 będzie faktycznie większa, jeśli uwzględni się także biblioteki, które tylko okresowo wydłużają godziny pracy w czasie sesji egzaminacyjnych. Warto też zauważyć, że gdyby dane prezentowane przez amerykańskie NCES przyłożyć do statystycznych wskaźników IFLA/ISO/UNESCO z podziałem bibliotek na cztery kategorie (biblioteki otwarte do 20 godzin w tygodniu, biblioteki otwarte od 20 do 40 godzin, następnie od 41 do 60 i powyżej 60), to okaże się, że zdecydowana większość bibliotek akademickich w USA należy do tej ostatniej kategorii, a właściwie jest poza kategorią. Oto bowiem według wspomnianego raportu z 2014 r. (dane z 2012) na 3793 sprawozdające biblioteki akademickie w USA aż 3012 otwartych było w przeciętnym tygodniu dłużej niż 60 godzin, z czego 595 bibliotek nawet powyżej 100 godzin w tygodniu (Academic Libraries, 2012, p. 2).

Mała stosunkowo liczba bibliotek uczelnianych dostępnych w przeciętnym tygodniu w pełnym wymiarze 168 godzin jest w sumie zrozumiała. Większość bibliotek dostosowuje bowiem swoje godziny pracy do kalendarza akademickiego, skracając czas pracy w dniach i w okresach, gdy statystyki wykazują mniejszą liczbę odwiedzin (weekendy, wakacje), a wydłużając czas pracy w końcówkach semestrów i w okresie sesji egzaminacyjnych. Dlatego, gdy mowa jest o całodobowej dostępności bibliotek, to patrząc na większość tygodni w kalendarzu, zamiast traktować dosłownie hasło 24/7, należałoby mówić o systemie 24/5 lub 24/4. Tylko bowiem przez kilka tygodni w roku, tam gdzie w ogóle praktykuje się całodobową dostępność, można mówić o czasowym obowiązywaniu systemu 24/7.

Przykładem wdrożenia systemu $24 / 5$ mogą być dwie główne biblioteki Uniwersytetu Stanowego North Carolina (NCSU) - Hill Library oraz Hunt Library. W roku akademickim 2019/2020, w semestrze jesiennym (od końca sierpnia do grudnia) oraz wiosennym (od stycznia do kwietnia) biblioteki te otwarte są przez całą noc od niedzieli do piątku (w piątek i w sobotę biblioteki zamykane są o 22:00, a w sobotę i w niedzielę otwarte są od 9:00 rano). W czasie egzaminów grudniowych i kwietniowo-majowych Biblioteki przechodzą na system 24/7, ale w sumie jest to tylko 20 dni w roku. W okresie letnim nie ma dni, kiedy Biblioteki otwarte byłyby 
przez 24 godziny, ale nawet w czasie wakacji dostępność godzinowa tych bibliotek może być dla użytkowników satysfakcjonująca, bo obie główne Biblioteki NCSU od poniedziałku do czwartku czynne są od 6:00 rano do 10:00 wieczorem (w piątki, soboty i niedziele nieznacznie krócej) ${ }^{12}$.

W dużym stopniu całodobowo, choć w skali roku w mniejszym stopniu niż w Bibliotekach NCSU, jest dostępna Biblioteka Uniwersytetu Stanowego w Kent w stanie Ohio (Kent State University). Biblioteka KSU, tak jak wiele innych bibliotek, dostosowuje system godzinowy do spodziewanej wielkości odwiedzin wynikającej z kalendarza akademickiego, więc plan godzinowy tygodnia pracy nie jest stały, ale zależny od pory roku. Zatem od końca sierpnia do końca listopada działa tu system 24/5 (w piątek i w sobotę zamyka się o 22:00). W okresie grudniowej sesji egzaminacyjnej przechodzi się na system 24/7, w styczniu tylko w niektóre dni biblioteka pracuje całą dobę, ale od lutego do maja następuje powrót do systemu 24/5, a w czasie egzaminów majowych znów na krótko wraca system 24/7. W okresie wakacyjnym godziny pracy ulegają oczywiście skróceniu, ale i w tym czasie Biblioteka KSU jest dostępna w szerokim zakresie czasowym, pracując $w$ dni powszednie ponad 14 godzin na dobę ${ }^{13}$.

Bardzo podobnie jak w Kent dostępność bibliotek w ciagu roku ustalono w Uniwersytecie Stanowym w Pensylwanii (Penn State University). Dwie główne Biblioteki tej uczelni - Pattee and Paterno Libraries - przez wiele tygodni w semestrze jesiennym i wiosennym są dostępne w systemie 24/5. W okresie grudniowej i kwietniowo-majowej sesji przechodzą na kilka dni na system 24/7, zaś w czasie wakacji skracają odpowiednio godziny, ale od poniedziałku do czwartku pracują co najmniej 13 godzin na dobę $e^{14}$.

\section{CAŁODOBOWA DOSTĘPNOŚĆ BIBLIOTEK W CZOŁOWYCH UCZELNIACH ŚWIATA}

Wydawać by się mogło, że na wprowadzenie systemu 24-godzinnego mogą sobie pozwolić biblioteki dużych, renomowanych i zamożnych uczelni. Tymczasem nie jest to wcale prawidłowość. Można bowiem łatwo wskazać uczelnie zajmujące czołowe miejsca w światowych rankingach, których biblioteki nie pracują dłużej niż do północy, jak też mniej prestiżowe uczelnie, których biblioteki udanie praktykują system całodobowy.

Oto $\mathrm{np}$. w rankingu czołowych uczelni świata prowadzonym przez magazyn „Times Higher Education” (THE World University Ranking)

\footnotetext{
${ }^{12}$ North Carolina State University - Libraries \& Hours: <https://www.lib.ncsu.edu/hours/hill/>, $<$ https://www.lib.ncsu.edu/hours/hunt/> [dostęp: 15.07.2019].

${ }^{13}$ KS University Libraries - Daily Hours: <https://www.library.kent.edu/daily-hours/> [dostęp: 15.07.2019].

${ }^{14}$ Penn State University Libraries - Monthly Hours: <https://libraries.psu.edu/monthly-hours/> [dostęp: 15.07.2019].
} 
piąte miejsce na świecie zajmuje Caltech czyli California Institute of Technology w Pasadenie. $Z$ ogólnego planu pracy w tygodniu wynika, że poszczególne biblioteki Caltech nie są otwarte dłużej niż do północy. Wyjątkiem jest Sherman Fairchild Library pracująca w niektórych tygodniach roku w systemie 24/5. Jednak zasady szczegółowe podaja, że studenci i pracownicy określonych wydziałów mogą - pod warunkiem posiadania legitymacji studenckiej (ID) - korzystać z wybranych bibliotek również w nocy. Na przykład studenci i pracownicy Wydziału Humanistycznego i Nauk Społecznych HSS (Humanities and Social Sciences) mogą w systemie 24-godzinnym korzystać z Dabney Library. Z kolei studenci i pracownicy Wydziału Geologii GPS (Geological and Planetary Sciences) mają 24-godzinny dostęp do Geology Library ${ }^{15}$.

Na czwartym miejscu w zestawieniu Times Higher Education jest inna renomowana politechnika - Massachusetts Institute of Technology. W ciągu roku są tygodnie, gdy niektóre biblioteki MIT otwarte są do północy, jak Hayden Library lub Rotch Library, albo przynajmniej do 23:00, jak Barker Library i Dewey Library. Ale żadna z bibliotek MIT nie jest otwarta przez 24 godziny ${ }^{16}$. Jednak dla studentów chcących uczyć się w nocy biblioteki MIT przygotowały pewne udogodnienie -3 pomieszczenia pod nazwa „24/7 study spaces” zlokalizowane w Barker Library, Dewey Library i Hayden Library. Nie są to przestrzenie szczególnie duże (największa z nich w Barker Library ma 90 miejsc), ale przede wszystkim nie jest to rozwiązanie zgodne z ideą biblioteki dostępnej w nocy. Okazuje się bowiem, że do tych trzech otwartych w nocy "study spaces" wchodzi się innym wejściem niż do biblioteki, a poza tym - co najważniejsze - w miejscach tych nie ma dostępu do zbiorów (oryg. There is no access to collections)! ${ }^{17}$

$\mathrm{Na}$ trzecim miejscu w rankingu "Times Higher Education" jest Uniwersytet Stanforda. Biblioteki tej uczelni, choć czynne wieczorami, jednak zamykane są najczęściej przed północą. Jedynie w Lathrop Library, jednej z bibliotek Uniwersytetu Stanforda, znajduje się 24-hour study room, otwarty całą dobę. Również w wakacje. Z tym że jest to „room”, a nie cała biblioteka ${ }^{18}$.

Dwa pierwsze miejsca w tym rankingu zajmują uniwersytety w Oksfordzie i w Cambridge, co nie zaskakuje, bo „Times Higher Education” jest wydawnictwem brytyjskim ${ }^{19}$. Pobieżna analiza może prowadzić do wnios-

\footnotetext{
${ }^{15}$ Caltech Library - Locations \& Hours: <https://www.library.caltech.edu/about/hours> [dostęp: 15.07.2019].

${ }^{16}$ MIT Libraries - Hours : <https://libraries.mit.edu/hours/> [dostęp: 15.07.2019].

${ }^{17}$ MIT Libraries - Study Spaces: <https://ibraries.mit.edu/study/24x7/> [dostęp: 15.07.2019].

${ }^{18}$ Stanford Libraries - Library hours: <https://library-hours.stanford.edu/> [dostęp: 15.07.2019].

${ }_{19} \mathrm{~W}$ tzw. rankingu szanghajskim uniwersytety w Oxford i Cambridge również zajmują wysokie pozycje w pierwszej dziesiątce na świecie, z tym że Oxford jest na miejscu 7, a Cambridge na 3. Zob. Academic Ranking of World Universities 2018: <http://www.shanghairanking.com/> [dostęp: 15.07.2019].
} 
ku, że w porównaniu z wymienionymi wcześniej czołowymi uczelniami amerykańskimi biblioteki tych dwóch brytyjskich uczelni pod względem dostępności godzinowej wypadają nieco gorzej. Ale taki wniosek można wysnuć, gdy weźmie się pod uwagę tylko biblioteki główne, bo jeśli spojrzeć na biblioteki z całego systemu kolegialnego tych uczelni, to okaże się, że dostępność godzinowa jest $w$ nich zdecydowanie lepsza.

A zatem Biblioteka główna zajmującego 2 miejsce w rankingu THE Uniwersytetu w Cambridge $w$ dni powszednie, w okresie od kwietnia do czerwca (tzw. Easter Full Term), pracuje do godziny 21:45, a w pozostałych miesiącach roku akademickiego tylko do 19:15². Biblioteki poszczególnych college'ów też w większości są otwarte tylko do wieczora, a czasem nawet wczesnego popołudnia. Jest kilka bibliotek, które pracują do północy lub nieco dłużej, jak Biblioteka w Queens' College otwarta do godziny 2:00 w nocy. Ale przede wszystkim jest wśród bibliotek kolegialnych i wydziałowych Cambridge University ponad 20 takich, które dla członków danej społeczności kolegialnej lub wydziałowej są dostępne non stop. Przykładem może być Lee Library w Wolfson College, która przez cały rok, z wyjątkiem tylko kilku dni w roku, jest dostępna w systemie $24 / 7^{21}$. Z kolei Jerwood Library w kolegium Trinity Hall podaje informację, że jest dostępna 365 dni w roku przez 24 godziny codziennie! ${ }^{22}$

Podobna sytuacja ma miejsce w Uniwersytecie w Oksfordzie, zajmującym pierwsze miejsce w rankingu THE. Główna biblioteka uczelni - Bodleian Library - w dni powszednie otwarta jest "tylko" do godziny 22:00. Jednak studentom planującym pracę w nocy, pozostałe 30 bibliotek działających w systemie biblioteki Bodleiańskiej oraz biblioteki poszczególnych kolegiów, oferują pod względem czasu dostępu dużo więcej ${ }^{23}$. W systemie bibliotecznym Uniwersytetu w Oksfordzie jest więc kilka bibliotek otwartych do późnych godzin nocnych, jak Lincoln College Library lub New College Library, które otwarte są do 2:00 w nocy. Ale przede wszystkim jest tu podobnie jak w Cambridge: ponad 20 bibliotek kolegialnych i wydziałowych dających członkom poszczególnych społeczności prawo wstępu przez całą dobę ${ }^{24}$.

\footnotetext{
${ }^{20}$ Cambridge University Library - Opening hours: $<$ http://www.lib.cam.ac.uk/full-opening-hours $>$ [dostęp: 15.07.2019].

${ }^{21}$ Wolfson College Cambridge - Library: <https://www.wolfson.cam.ac.uk/current-students/library> [dostęp: 15.07.2019].

${ }^{22}$ Cambridge Libraries - Trinity Hall: <https://www.libraries.cam.ac.uk/libraries-directory/trinityhall> [dostęp: 15.07.2019].

${ }^{23}$ Bodleian Libraries - Opening Hours: <https://www.bodleian.ox.ac.uk/subjects-and-libraries/ opening-hours> [dostęp: 15.07.2019].

${ }^{24}$ Najbardziej zwięźle i dobitnie wśród bibliotek Uniwersytetu Oksfordzkiego o swoich godzinach otwarcia informuje Sir William Dunn School of Pathology Library. Informacja jest następująca: „Term hours \& Vacation hours: Always open to departmental members ; Closed: Does not close”. Zob. $<$ https://www.bodleian.ox.ac.uk/subjects-and-libraries/opening-hours>.
} 
Zrozumiałe jest, że całodobowa dostępność bibliotek uczelnianych, zwłaszcza tych stosunkowo niewielkich bibliotek kolegialnych, polega na tym, że od pewnej godziny po południu (często jest to godzina 17:00) biblioteki te działają w trybie bezobsługowym (unstaffed). Wiele w tym względzie wyjaśnia uwaga przy informacji o dostępności St. Cross College Library w Oksfordzie, gdzie podano: "Twenty four hours throughout year for all Members of College with a key"! W małej bibliotece uczelnianej rozwiązanie jest więc proste. Student danego collegu dysponuje uniwersalnym kluczem, otwierającym drzwi do akademika, do pokoju studenta i do biblioteki. Może więc iść do biblioteki o dowolnej porze, również $\mathrm{w}$ czasie, gdy biblioteka pracuje $\mathrm{w}$ trybie bezobsługowym i sam ją sobie otworzyć. Takie rozwiązanie widać sprawdza się w bibliotekach kolegialnych, które działają trochę jak biblioteki domowe. Ale w dużej bibliotece uczelnianej, której zbiory liczone są w setkach tysięcy albo i milionach woluminów, dysponującej wieloma pomieszczeniami, rozlokowanymi czasem na kilku piętrach, zorganizowanie dostępu do biblioteki wymaga jednak większego sformalizowania i odpowiedniego poziomu kontroli.

Ten krótki przegląd dostępności godzinowej bibliotek w kilku czołowych uczelniach świata wyjaśnia, dlaczego według danych statystycznych, biblioteki uczelni brytyjskich wypadają w tej kategorii najlepiej. Obliczył to kiedyś Matthew Reisz z magazynu "Times Higher Education”, a podał w tekście pod znamiennym tytułem "Chcesz iść do biblioteki o 3:00 w nocy? Wielka Brytania to właściwe miejsce”. Okazało się, że według danych serwisu „Times Higher Education”, gromadzonych w ramach World University Rankings, odsetek bibliotek z czołowych uczelni świata, które dawały swym użytkownikom dostęp przez 24 godziny na dobę wyniósł 8,5\%, ale w grupie zawężonej do bibliotek uczelni brytyjskich ten odsetek wzrósł do 24\% (Reisz, 2010).

\section{MIEJSCE Z GNIAZDKIEM I INNE UDOGODNIENIA}

W wielu publikacjach zajmujących się organizacją pracy bibliotek i wydłużaniem godzin ich pracy w porze nocnej powtarza się istotna teza, którą David Schwieder i Laura I. Spears przedstawiają jako pewną prawidłowość. Polega to na tym, że nocni użytkownicy oczekują od biblioteki przede wszystkim miejsca do nauki z odpowiednimi udogodnieniami, jak chociażby gniazdka elektryczne. Natomiast w mniejszym stopniu zależy im na korzystaniu ze zbiorów biblioteki i pomocy ze strony personelu bibliotecznego (Schwieder \& Spears, 2017, p. 3). Dobitnie świadczą o tym wyniki badań ankietowych przeprowadzonych przez Schwiedera i Spears wśród użytkowników Biblioteki Uniwersytetu na Florydzie. Na pytanie o to, czego nocni użytkownicy oczekują od biblioteki i z czego chcą korzystać, najczęściej wśród możliwych odpowiedzi respondenci 
wskazywali odpowiedź "gniazdko elektryczne” (90\% wskazań), a drugą i trzecią pozycję w tym zestawieniu zajęły "miejsca do cichej nauki” i „kawiarnia”. Jednocześnie tylko 19\% respondentów deklarowało chęć korzystania ze zbiorów bibliotecznych (Schwieder \& Spears, 2017, p. 7). Nieco większy odsetek osób deklarujących chęć korzystania w nocy ze zbiorów bibliotecznych zanotowano podczas badań przeprowadzonych w Bibliotece Uniwersytetu Stanowego Minnesota (MSU) w miejscowości Mankato. Generalnie jednak we wszystkich tego typu badaniach stwierdza się, że studenci oczekuja, iż biblioteka otwarta w nocy stworzy im przede wszystkim przestrzeń do spokojnej nauki. W Bibliotece MSU przebadano studentów korzystających z biblioteki uczelnianej między północą a godziną 2:00. Na pytanie o powód korzystania z biblioteki w godzinach nocnych wśród możliwych do wyboru odpowiedzi można było wskazać chęć skorzystania ze zbiorów drukowanych. Ale tę opcję (przy możliwości wielokrotnego wyboru) wskazało tylko $31 \%$ uczestników badania. Tymczasem najczęściej, bo przez $84 \%$ respondentów, wybierana była odpowiedź, że powodem nocnej wizyty w bibliotece była po prostu chęć cichej nauki (Lawrence \& Weber, 2012, p. 535).

$\mathrm{W}$ analizach dotyczących nocnego korzystania z bibliotek jako problem badawczy pojawia się też kwestia czasu poświęconego przez użytkowników na nocną pracę w bibliotece. W domyśle zaś pojawia się kategoria użytkowników całonocnych. Praktyka pokazuje, a wynika to z całodobowych pomiarów liczby odwiedzin w różnych bibliotekach, że różnica między liczbą osób, które przebywają w bibliotece około północy a liczbą tych, którzy zostają do rana, jest znaczna. Można więc przyjąć, że całonocnych użytkowników jest niewielu, mimo że z deklaracji użytkowników wynikałoby, że wielu z nich byłoby gotowych spędzić w bibliotece całą noc. Świadczą o tym wyniki badania opisanego przez Maureen Richards, a przeprowadzonego wśród użytkowników biblioteki w Szkole Prawa Karnego Uniwersytetu w Nowym Jorku (John Jay College of Criminal Justice City University of New York). Stwierdzono mianowicie, że tylko $4 \%$ spośród osób odwiedzających bibliotekę w godzinach nocnych deklarowało chęć spędzenia tam czasu w wymiarze jednej-dwóch godzin, 45\% użytkowników planowało pracę od trzech do sześciu godzin, zaś około 50\% nocnych użytkowników zamierzało spędzić w bibliotece siedem i więcej godzin (Richards, 2016, p. 10). Rozbieżność między deklarowanym czasem pracy a praktyką wynikającą z pomiarów wynika zapewne z faktu, że praca w nocy jest dla wielu osób jednak poważnym fizjologicznym wyzwaniem, dlatego nieliczni spośród tych, którzy przychodzą do biblioteki w godzinach wieczornych, rzeczywiście zostają w niej do samego rana. Z drugiej strony do mniejszości należą też ci, którzy na nocną pracę $\mathrm{w}$ bibliotece zamierzają poświęcić mniej niż dwie godziny. I nie jest to zaskoczeniem, bo w porze nocnej, gdy zamknięta jest wypożyczalnia, $\mathrm{w}$ bibliotece nie mają potrzeby poja- 
wiać się „przelotni użytkownicy”, których w ciągu dnia jest wielu, a którzy przychodzą na krótko, by coś wypożyczyć, czy odebrać złożone wcześniej zamówienie. $W$ godzinach nocnych takich osób zatem nie ma, natomiast przeważają osoby, które chcą w nocy w bibliotece spędzić więcej czasu, przynajmniej trzy-cztery godziny. Z tego zaś wynika kilka oczywistych, lecz istotnych wniosków.

Po pierwsze zatem, osoba spędzająca w bibliotece większą część nocy będzie prawdopodobnie chciała skorzystać z toalety. Biblioteka powinna więc zapewnić nieprzerwany dostęp do toalet i zadbać o ich pełną funkcjonalność nie tylko za dnia. Dłuższa niż normalnie przerwa w zabiegach o utrzymanie czystości toalet, nawet przy zmniejszonej liczbie użytkowników, może spowodować w tym zakresie pewne problemy. Po drugie, osoba pracująca $\mathrm{w}$ bibliotece wiele godzin zapewne będzie mieć potrzebę pożywienia się i skorzystania $z$ napojów. W opcji minimum należy więc dać użytkownikom dostęp do automatów z napojami i prostymi produktami spożywczymi. W bardziej zaawansowanej opcji należy zadbać o to, by funkcjonujące w budynku biblioteki kawiarnia, bar czy lokal typu fast casual pracowały w tym samym czasie co biblioteka, albo przynajmniej w pewnych okresach wydłużały czas pracy ponad przyjęty standard. Po trzecie wreszcie, osoba spędzająca w bibliotece długie godziny może - zwłaszcza w godzinach nocnych - odczuwać znużenie. Choć więc zasadniczo biblioteka nie jest miejscem dla osób szukających noclegu, to jednak warto zadbać o to, by wśród bibliotecznego umeblowania znalazły się sprzęty typu leżaki czy pufy, z których mogą chcieć skorzystać użytkownicy potrzebujący chwili relaksu i odprężenia.

\section{ZNACZENIE BIBLIOTEK JAKO MIEJSC}

Potrzeba korzystania z bibliotek w nocy, w czasie gdy najczęściej ich funkcjonalność jest częściowo ograniczona, świadczy szczególnie o tym, jak duże znaczenie ma dla użytkowników to, że stwarzają one po prostu wygodne miejsce do pracy. W kontekście owej wygody przypomina się wypowiedź Jamesa Thompsona, szefa biblioteki Uniwersytetu w Reading (Anglia), (zm. w 2015 r.), który w swej głośnej książce z 1982 r. pt. The end of libraries, kwestionował tę wygodę (w oryg. convenience), gdy pisał o nienadającej się do użytku bibliotece (unusable library), najczęściej zbyt dużej i zbyt szybko powiększającej się, by z niej efektywnie korzystać, w zbyt skomplikowany sposób uporządkowanej i do tego zbyt drogiej w utrzymaniu (Thompson, 1982, pp. 7-14). Pisał też, że: „Problem $\mathrm{z}$ bibliotekami polega na tym, że w absolutnym sensie nigdy nie mogą być wygodne. A wygoda dla osoby poszukującej informacji polega na udostępnieniu lub dostarczeniu informacji tam, gdzie jest; w swoim biurze, w swoim laboratorium, w domu" (Thompson, 1982, p. 26). Uznanie biblio- 
teki za niewystarczająco efektywną czy niewygodną skłania do polemiki z Thompsonem. Bowiem nie dla każdego celem wizyty w bibliotece jest poszukiwanie informacji. Niektórzy udają się tam po prostu w poszukiwaniu miejsca do pracy. A informacje, jakie podczas tej pracy można zdobyć, czy to korzystając ze zgromadzonych w bibliotece zbiorów, czy też $z$ dostępu online do wszelakich baz abonowanych przez bibliotekę, są niejako dodatkiem do owego miejsca. Skupiając się na informacyjnej funkcji biblioteki, Thompson przesunął na dalszy plan ten istotny w ocenie biblioteki czynnik, jakim jest odpowiednia aranżacja przestrzeni i atmosfera sprzyjająca intelektualnemu wysiłkowi. W czasach, gdy Thompson pisał „Koniec bibliotek”, zachłyśnięcie się możliwościami technologii komputerowej, która zapowiadała - z tamtej perspektywy - głębokie przeobrażenie bibliotek, było w sumie zrozumiałe. Pojawienie się możliwości gromadzenia coraz większych ilości informacji na coraz mniejszych przestrzeniach fizycznych oraz przesyłania na odległość coraz większych porcji danych w coraz krótszym czasie musiało obserwatorów z lat 70. czy 80. XX w., bez wątpienia fascynować i pociągać. Dziś jednak, w czasach gdy odbiorca korzysta z płynnego i doskonałego jakościowo przesyłu obrazów i sygnałów dźwiękowych, szybkość i wielkość przesyłu danych już tak nie zadziwia. Po latach fascynacji nową technologia, znajdującą szerokie zastosowanie także w bibliotekarstwie, należy na powrót spojrzeć na bibliotekę jak na przyjazne miejsce do spędzania czasu w różny sposób - zarówno w celu gromadzenia informacji i dla własnej nauki, jak też w celach rozrywkowych czy towarzyskich.

\section{NOWY BIBLIOTECZNY PARADYGMAT}

W środowisku bibliotekarskim od dłuższego czasu dyskutuje się o zasadniczej zmianie paradygmatu opisującego istotę i funkcje biblioteki. Mówi się w tym kontekście o przejściu od paradygmatu czytelniczego (reading paradigm) do paradygmatu uczenia się (learning paradigm) (Favier, 2014, pp. 196-197). Inny sposób opisu zmiany tego paradygmatu w odniesieniu do bibliotek akademickich zawiera się w stwierdzeniu, że w szkolnictwie wyższym następuje przejście od kultury nauczania do kultury uczenia się. Szczególnie dobitnie zmianę tę ujął Scott Bennett w zdaniu o zadaniach współczesnych bibliotekarzy, pisząc: „Naszym celem nie jest obieg książek, ale zapewnienie, że obieg wiedzy sprzyja uczeniu się" (Bennett, 2005, pp. 10-11) 25. Wydaje się jednak, że owa zmiana paradygmatu głównie wyraża się tym, że kluczowymi terminami opisującymi istotę biblioteki przestają być przede wszystkim słowa „zbiór, kolekcja, maga-

${ }^{25}$ Oryg.: Our purpose is not to circulate books, but to ensure that the circulation of knowledge produces learning. 
zyn”, a na czoło w opisie tej istoty wysuwa się słowo „miejsce”. Stąd tak liczne w piśmiennictwie bibliotekoznawczym wypowiedzi pod hasłem „library as a place”.

Jeszcze do niedawna biblioteka była przede wszystkim postrzegana jako zbiór, przy którym stworzono miejsce do pracy. Dziś na odwrót jest coraz częściej opisywana jako miejsce, w którym są odpowiednie warunki do pracy, a zbiór jest jednym z narzędzi, które tę pracę mają ułatwić. Zwraca przy tym uwagę nowe nazewnictwo. Coraz częściej bowiem w języku angielskim, obok określenia „,biblioteka”, a nawet alternatywnie do niego, szczególnie $\mathrm{w}$ opisie struktury bibliotek akademickich, stosuje się określenia „learning commons" lub „information commons", co ma się odnosić do funkcjonalnej przestrzeni edukacyjnej, odpowiednio zaaranżowanej, wyposażonej w niezbędne urządzenia techniczne i ewentualnie dającej dostęp do zbioru dokumentów ${ }^{26}$.

Mogąc pracować w otoczeniu uporządkowanych tematycznie i wyselekcjonowanych merytorycznie książek i czasopism współczesny użytkownik biblioteki zyskuje komfort pracy. Jest w miejscu harmonizującym pracę naukową i tchnącym inspiracją. Nie musi koniecznie sięgać po te wszystkie wartościowe książki i czasopisma, bo często równie wartościowe ekwiwalenty znajduje w sieci. Ale wpatrzony w ekran laptopa ma jednak poczucie bycia we właściwym otoczeniu, stwarzającym odpowiednią atmosferę. Docenia też to - skupiając się niekiedy na źródłach cyfrowych - że może jednak w każdej chwili sięgnąć na półkę po encyklopedię czy podręcznik lub po archiwalny zeszyt drukowanego czasopisma.

O tym, że współczesny użytkownik biblioteki, a zwłaszcza biblioteki naukowej, wybiera często to miejsce przede wszystkim jako miejsce do pracy, niekoniecznie $z$ zamiarem wykorzystania zgromadzonych $w$ niej zbiorów, przekonują także autorzy opracowania pt. „Scenariusze przyszłości bibliotek”, pisząc: „Biblioteka to nie tylko zbiór książek, to także konkretna przestrzeń, w której można z nimi obcować w komfortowych warunkach, uczyć się lub pisać, także bez udziału książek, korzystając z atmosfery ciszy i skupienia" (Tarkowski \& Bendyk, 2011, s. 18). Z marketingowego punktu widzenia bez wątpienia korzystne dla bibliotek jest stawianie ich $\mathrm{w}$ jednym rzędzie $\mathrm{z}$ muzeami, galeriami i innymi miejscami określanymi zbiorczo jako przestrzenie publiczne czy miejsca publiczne. Jednak będąc jedną $z$ ważnych i niezbędnych przestrzeni publicznych, biblioteka pozostaje instytucją wypełniającą specyficzne zadania. Nie jest więc miejscem do spędzania czasu w jakikolwiek sposób, ale jednak w sposób z definicji ukierunkowany. $\mathrm{W}$ „Scenariuszach przyszłości bibliotek" autorzy rozważaja, jakie miejsca mogłyby pełnić rolę alternatywy

${ }^{26}$ Zob. np.: Learning Commons [online]. Indiana University Bloomington: <https://libraries. indiana.edu/learning-commons> [dostęp: 20.08.2019]. 
dla bibliotek, pisząc, że mogą nimi być „(...) centra handlowe, księgarnie sieciowe, kluboksięgarnie, kawiarnie, domy kultury, świetlice, remizy, instytucje rekreacyjne i relaksacyjne (gabinety masażu, szkoły jogi, sauny, spa), kluby sportowe. W mniejszym stopniu przestrzenie publiczne - place, parki, ulice, środki transportu publicznego, kościoły" (Tarkowski \& Bendyk, 2011, s. 22). Nasuwa się jednak pytanie, w którym z wymienionych miejsc publicznych człowiek potrzebujący ciszy i skupienia, żeby opracować jakiś materiał, przygotować się do egzaminu, napisać fragment dysertacji, przygotować recenzję itd., zrobi to tak sprawnie, jak w bibliotece. Odpowiedź jest oczywista - w żadnym.

\section{ZAKOŃCZENIE}

Dostęp online do elektronicznych źródeł informacji, uzyskiwany o dowolnej porze $z$ dowolnych lokalizacji, poprzez urządzenia stacjonarne i mobilne, ma bez wątpienia wiele zalet, ale nie zaspokaja wszystkich potrzeb osób uczących się i prowadzących badania. A wśród tych potrzeb wciąż znacząca jest potrzeba skorzystania z miejsca, dającego komfort pracy w ciszy i w skupieniu lub możliwość pracy grupowej. Dla wielu osób takim miejscem jest przede wszystkim biblioteka - otwarta również w godzinach wieczornych i w nocy. Nocnymi użytkownikami bibliotek są zwłaszcza studenci, a potrzebę tę przejawiają szczególnie w okresach sesji egzaminacyjnych. Utrzymywanie przez całą dobę dostępności biblioteki akademickiej jako miejsca do nauki nie należy dziś do rzadkości, choć potwierdzana w różnych badaniach znikoma liczebność użytkowników obecnych w bibliotece na granicy nocy i dnia skłania do stawiania pytań o ekonomiczne uzasadnienie wprowadzania systemu całodobowego. $\mathrm{Z}$ drugiej jednak strony wykazywane w tych samych badaniach duże zainteresowanie możliwością korzystania z biblioteki o północy, a nawet w środku nocy, przekonuje o słuszności wydłużania godzin pracy bibliotek uczelnianych, a zamykanie bibliotek w dużych ośrodkach akademickich przed godziną 20:00 każe uznać za anachronizm.

\section{BIBLIOGRAFIA:}

Academic Libraries (2010). Academic Libraries: 2010 First Look [online]. National Center for Education Statistics. U.S. Department of Education [dostęp: 10.07.2019]. Dostępny w WWW: <https://nces.ed.gov/pubs2012/2012365.pdf>.

Academic Libraries (2012). Academic Libraries: 2012 First Look [online]. National Center for Education Statistics. U.S. Department of Education [dostęp: 10.07.2019]. Dostępny w WWW: <https://nces.ed.gov/pubs2014/2014038.pdf>.

Bennett, Scott (2005). Righting the Balance [in:] Library as Place: Rethinking Roles, Rethinking Space. Washington, D.C.: CLIR, pp. 10-24. 
Bowman, Adam C. (2013). 24-Hour Academic Libraries: Adjusting to Change. Journal of Access Services, vol. 10, iss. 4, pp. 217-239.

Breakenridge, Susan (2017). 24/7 Library Operations - Will They Actually Come? [online]. Evidence Based Library and Information Practice, vol. 12, no. 4 [dostęp: 15.07.2019]. Dostępny w WWW: <https://journals.library.ualberta.ca/eblip/index.php/EBLIP/article/ view/29313/21449>.

Chant, Ian (2013). USF library again open 24 hours after student protest. Library Journal, no. 16, p. 18.

Chrzastowski, Tina E.; Nutefall, Jennifer E. (2016). Is everything all right at night? Measuring user response to overnight library services. Journal of Access Services, vol. 13, iss. 3, pp. 179-198.

Davis, Denise M. (2011). Trends in Academic Libraries, 1998 to 2008 [online]. American Library Association [dostęp: 20.08.2019]. Dostępny w WWW: <http://www.ala.org/tools/ sites/ala.org.tools/files/content/librarystats/academic/ALS\%209808\%20comparison. pdf $>$.

Davis, Noelle; Liu, Tim; Zhu, Richard (2017). Caltech's Incredible, Shrinking Library [online]. The California Tech oct. 17, vol. CXXI, no. 4, p. 1 [dostęp: 19.08.2019]. Dostępny w WWW: <https://caltechcampuspubs.library.caltech.edu/3229/1/Issue $\% 204 \% 2 C \% 20$ 2017-18.pdf>.

Dol, Justine; et. al. (2012). „Late Night with McLaughlin”: Library usage during late evening hours [online], [dostęp: 19.07.2019]. Dostępny w WWW: <https://www.researchgate.net/publication/306254020_Late_Night_with_McLaughlin_Library_usage_during_late_evening_hours>.

Eco, Umberto (2007). O bibliotece. Warszawa: Świat Książki.

Engel, Debra; Womack, Kay; Ellis, Ursula (2002). Opening a Library 24 Hours. Journal of Library Administration, vol. 36, iss. 4, pp. 95-108.

Favier, Laurence (2014). Library as place at the digital age. [w:] Nauka o informacji w okresie zmian. Koncepcje, metody, badania, praktyki. Praca zbior. pod red. B. Sosińskiej-Kalaty; przy udziale M. Przastek-Samokowej i Z. Wiorogórskiej. Warszawa, Wydaw. SBP, s. $195-205$.

Francis, Simon (2009). Academic libraries and the financial crisis: experiences from Britain. Zarzadzanie Biblioteka, nr 1, s. 121-133.

Johnson, Ken; McCallister, Kelly (2015). Assessing the 24/5 Library: A Case Study in Data and Perspectives. Journal of Access Services, vol. 12, iss. 3-4, pp. 75-90.

Laaker, Sarah (2011). Keeping the Doors Open: Exploring 24-Hour Library Access at Washington University in St. Louis [online]. Research Library Issues: A Quarterly Report from ARL, CNI, and SPARC, no. 277, dec. 2011, pp. 15-25 [dostęp: 5.07.2019]. Dostępny w WWW: <https://publications.arl.org/rli277/16>.

Lawrence, Peg; Weber, Lynne (2012). Midnight-2.00 a.m.: what goes on at the library? New Library World, vol. 113, iss. 11/12, pp. 528-548.

L.K. (1993). Carnegie Mellon student protest gets library hours restored. American Libraries, vol. 24, iss. 10, pp. 903-905.

Manguel, Alberto (2008). The library at night. New Haven, London: Yale University Press.

Reisz, Matthew (2010). You Want to Go to the Library at $3 \mathrm{am}$ ? Britain's the Place [online]. Times Higher Education, sept. 9, 2010 [dostęp: 25.07.2019]. Dostępny w WWW: <https:// www.timeshighereducation.com/news/you-want-to-go-to-the-library-at-3am-britains -the-place/413398.article>. 
Richards, Maureen (2016). 24/7 Library Hours at an Urban Commuter College [online]. Urban Library Journal, vol. 22, iss. 1, art. 2 [dostęp: 18.07.2019]. Dostępny w WWW: $<$ http://academicworks.cuny.edu/ulj/vol22/iss1/2>.

Ryan, Nicky (2014). Students stage 'study-in' at UCC library over opening hours [online]. TheJournal.ie 2014 dec. 9th [dostęp: 12.08.2019]. Dostępny w WWW: <https://www.thejournal.ie/ucc-campus-library-opening-hours-protest-sit-in-1823819- Dec2014/>.

Sanders, Mark; Hodges, Chris (2014). An Overnight Success?: Usage Patterns and Demographics of Academic Library Patrons During the Overnight Period From 11 p.m.-8 a.m. Journal of Access Services, vol. 11, iss. 4, pp. 309-320.

Schwieder, David; Spears, Laura I. (2017). Studying the Night Shift: A Multi-method Analysis of Overnight Academic Library Users [online]. Evidence Based Library and Information Practice, vol. 12, no. 3 [dostęp: 18.07.2019]. Dostępny w WWW: <https://journals. library.ualberta.ca/eblip/index.php/EBLIP/article/view/28945/21416>.

Sewell, Bethany B. (2013). 24-Hour Access: Responding to Students' Need for Late Library Hours at the University of Denver. Journal of Access Services, vol. 10, iss. 1, pp. 14-27.

Sowell, Steven L.; Nutefall, Jennifer E. (2014). Mysteries in the Night: An Exploratory Study of Student Use and Perceptions of 24/5 Hours. Public Services Quarterly, vol. 10, iss. 2, pp. 96-114.

Tarkowski, Alek; Bendyk, Edwin (2011). Scenariusze przyszłości bibliotek. Warszawa: Fundacja Rozwoju Społeczeństwa Informacyjnego.

Thompson, James (1982). The end of libraries. London: C. Bingley.

Artykuł w wersji poprawionej wptynąt do Redakcji 13 listopada 2019 r.

Dariusz Grygrowski

Faculty of Journalism, Information and Book Studies

University of Warsaw

e-mail: dargry@uw.edu.pl

ORCID: 0000-0003-2155-2931

\section{ACADEMIC LIBRARIES AT NIGHT - PART ONE - FOREIGN EXPERIENCE}

KEYWORDS: Academic libraries - organization and management. Academic libraries hours. Academic libraries - night services.

ABSTRACT: Thesis/Objective - Availability of all services twenty four hours a day and seven days a week usually is abbreviated as $24 / 7$. With regard to library services it means not only virtual, remote access to library resources and services but also permanent, physical access to library reading rooms and collections stored there. However, there are not many libraries in the world open round the clock. On the other hand there is an emerging tenden- 
cy to extend library hours, in particular academic libraries do that in response to students' needs. The aim of this article is to present foreign academic library experience as regards night library services. Research methods - The author analyzed literature on library organization and management, focusing on the publications discussing the results of research on the use of libraries at night. In addition regular and non-standard academic library hours displayed on the library websites were analyzed. Results and conclusions - Studies on user needs and night library user counters definitely show that extended library hours are justified. The decreasing number of library users during late night hours is obvious and expected. However, the number of users interested in onsite access to academic library collections around midnight (or even later) usually is so high that justifies the decision to extend library hours in selected periods of an academic year. 